\title{
Czym są epistemiczne układy odniesienia?
}

\section{Uwagi wstępne}

Niniejszy tekst, odpowiadając na tytułowe pytanie, koncentruje się na dwóch sprawach. Po pierwsze, wyjaśnia, jakiego rodzaju warunkami sine qua non są epistemiczne układy odniesienia (EUO). Po drugie, wskazuje na potrzebę oddzielania EUO od programów badawczych i paradygmatów oraz przedstawia dwójkę dobrych kandydatów na nośniki EUO. Wyjaśnienia te obszernie korzystają z osiągnięć ZGL „Nauka a Religia”: z Serwisu Filozoficznego „Nauka a Religia”; czasopisma internetowego Filozoficzne Aspekty Genezy; serii książkowej Biblioteka Filozoficznych Aspektów Genezy oraz licznych prac członków ZGL publikowanych w innych czasopismach i seriach książkowych.

W paragrafie drugim podkreślam fakt, że omawiane do tej pory EUO nigdy nie pełniły roli kryterium demarkacji. Wyjaśniam również, dlaczego tak się sprawy mają oraz dlaczego EUO pełnią rolę jedynie warunków sine qua non uprawiania nauki. Na przestrzeni dziejów sformułowano jednak sporo warunków koniecznych naukowości. Pojawia się zatem pytanie o to, czy EUO są w jakiś sposób warunkami wyróżnionymi. Wraz z pozytywną odpowiedzią na to pytanie wprowadzam dwie dystynkcje: mocne i słabe oraz materialne i formalne warunki sine qua non. Wspomniane dystynkcje pozwalają dostrzec wyróżniony status EUO na tle innych warunków naukowości.

Dr hab. Krzysztof J. KiLIAN, PROF. UZ - Uniwersytet Zielonogórski, e-mail: kiliankrzysztof @yahoo.pl.

(C) Copyright by Krzysztof J. Kilian \& Filozoficzne Aspekty Genezy. 
Paragraf trzeci dotyczy problemu sensowności oddzielania EUO od programów badawczych i paradygmatów. Na pierwszy rzut oka EUO mogą być składnikami Popperowskich metafizycznych programów badawczych oraz twardych rdzeni Lakatosowskich naukowych programów badawczych, pełniąc w tych ostatnich rolę mocnych zasad heurystycznych, kierujących badaniami naukowymi. EUO można też próbować umieszczać w Kuhnowskich macierzach dyscyplinarnych, gdzie mogą funkcjonować jako składnik wartości lub modeli ontologicznych. Przytaczam racje na rzecz oddzielania EUO od wspomnianych struktur. Wskazuję też, że na nośniki EUO, lepiej niż te struktury, nadają się na Feyerabendowskie interpretacje naturalne i Lakatosowskie podstawowe sądy wartościujące.

\section{EUO jako mocne, materialne warunki sine qua non naukowości}

W ramach badanego tu ujęcia funkcjonują cztery EUO, które układają się w następujące pary:

naturalizm antynadnaturalistyczny — nadnaturalizm;

naturalizm antyartyficjalistyczny — artyficjalizm.

Epistemiczny układ odniesienia naturalizmu antynadnaturalistycznego to nakaz przyjmowania jedynie naturalistycznych wyjaśnień dla faktów i procesów, któremu towarzyszy zakaz przyjmowania wyjaśnień antynaturalistycznych, pojmowanych jako zakaz powoływania się na przyczyny nadnaturalne.

Epistemiczny układ odniesienia nadnaturalizmu to nakaz dopuszczania w wyjaśnianiu zjawisk przyrodniczych obok przyczyn naturalnych również wyjaśnień odwołujących się do przyczyn nadnaturalnych — interwencji bytu nadprzyrodzonego, czyli Boga.

Epistemiczny układ odniesienia naturalizmu antyartyficjalistycznego to nakaz przyjmowania jedynie naturalistycznych wyjaśnień dla faktów i procesów, któremu towarzyszy zakaz przyjmowania wyjaśnień antynaturalistycznych, pojmowanych jako zakaz powoływania się na przyczyny sztuczne (inteligentne, celowe). 
Epistemiczny układ odniesienia artyficjalizmu to nakaz dopuszczania w badaniach naukowych obok przyczyn naturalnych również przyczyn sztucznych, inteligentnych. ${ }^{1}$

Przebadane do tej pory EUO: naturalizmu, nadnaturalizmu i artyficjalizmu to, przyjmowane na mocy decyzji uczonych, niewielkie, dwu- lub trzyelementowe, zbiory najogólniejszych, historycznie zmiennych założeń, które mówią wyłącznie to, jak należy i jak nie należy uprawiać nauki. ${ }^{2}$ Są zatem jedynie koniecznymi warunkami uprawiania nauki. ${ }^{3}$ Jako takie, nie wyznaczają kryterium

Por. Krzysztof. J. KiLıan, „Geneza idei epistemicznych układów odniesienia i ich odmiany”, Filozoficzne Aspekty Genezy 2017, t. 14, s. 159-164 [137-190], http://www.nauka-a-religia.uz. zgora.pl/images/FAG/2017.t.14/art.05.pdf (08.04.2018).

${ }^{2}$ Por. wypowiedź Kazimierza Jodkowskiego w: Adam Willma, „Przyroda, Bóg, nauka. Rozmowa z profesorem Kazimierzem Jodkowskim”, Gazeta Pomorska 2 listopada 2006, s. 7, www. nauka-a-religia.uz.zgora.pl/images/Przedruki/Jodkowski Przyroda.Bog.nauka.pdf (18.01.2018); Kazimierz Jodкowski, „Dlaczego kreacjonizm jest pseudonauką?”, w: Józef Zon (red.), Pogranicza nauki. Protonauka - paranauka - pseudonauka, Wydawnictwo KUL, Lublin 2009, s. 322 [317-323], www.nauka-a-religia.uz.zgora.pl/images/Przedruki/Jodkowski_Dlaczego.kreacjonizm. jest.pseudonauka.pdf (31.01.2018); Kazimierz JoDKowski, „Nienaukowy fundament nauki”, w: Zbigniew Pietrzak (red.), Granice nauki, Lectiones \& Acroases Philosophicae 2013, vol. VI, nr 1, s. 100-105 [59-108], www.nauka-a-religia.uz.zgora.pl/images/Przedruki/Jodkowski Nienauko wy.fundament.nauki.pdf (12.02.2018); Kazimierz JoDKowsKI, „Eskapizm teologii i filozofii katolickiej w sprawie «nauka a religia»", Na Poczatku... 2005, nr 7-8 (196-197), s. 273-274 [261284], www.nauka-a-religia.uz.zgora.pl/images/Przedruki/Jodkowski_Eskapizm.teologii.i.filozofii. katolickiej.pdf (18.02.2018); Kazimierz JoDKOwSKI, „Zasadnicza nierozstrzygalność sporu ewolucjonizm-kreacjonizm”, Przeglad Filozoficzny - Nowa Seria 2012, nr 3 (83), s. 215 [201-222], www.nauka-a-religia.uz.zgora.pl/images/Przedruki/Jodkowski Zasadnicza.nierozstrzygalnosc.spo ru.ewolucjonizm.kreacjonizm.pdf (18.02.2018); Kazimierz JoDKowsKI, „Epistemiczny układ odniesienia teorii inteligentnego projektu”, Filozofia Nauki 2006, nr 1 (53), s. 97-98 [95-105], www. nauka-a-religia.uz.zgora.pl/images/Inne.teksty/Jodkowski_Epistemiczny.uklad.odniesienia.teorii.I D.pdf (98.02.2018); Grzegorz BUGAJAK, „Adekwatność tezy o rozdzielności płaszczyzn poznawczych. Głos w imieniu mieszkańców «opancerzonego bunkra»", w: Piotr ByLICA, Krzysztof J. Kilian, Robert Piotrowski i Dariusz SAgAN (red.), Filozofia - nauka - religia. Ksiega jubileuszowa dedykowana Profesorowi Kazimierzowi Jodkowskiemu z okazji 40-lecia pracy naukowej, Oficyna Wydawnicza Uniwersytetu Zielonogórskiego, Zielona Góra 2015, s. 179 [173-190], www.nauka-a-religia.uz.zgora.pl/images/Przedruki/Bugajak_Adekwatnosc.tezy.o.rozdzielnosci.pl aszczyzn.poznawczych.pdf (10.02.2018).

${ }^{3}$ Por. Piotr Bylica, Krzysztof J. Kilian i Dariusz Sagan, „Wstęp”, w: Bylica, Kilian, Piotrowski i SAGAN (red.), Filozofia - nauka - religia..., s. 18 [11-33], http://www.nauka-a-reli gia.uz.zgora.pl/images/Przedruki/Filozofia.nauka.religia.pdf (15.01.2018); Piotr BYLICA, Wspólczesny teizm naturalistyczny $z$ punktu widzenia modelu poziomów analizy. Problem działania sfery nadnaturalnej w przyrodzie, Biblioteka Filozoficznych Aspektów Genezy, t. 7, Instytut Filozofii Uniwersytetu Zielonogórskiego, Zielona Góra 2016, s. 26, 206-207, www.nauka-a-religia. 


\section{demarkacji. ${ }^{4}$}

Ani naturalizm, ani antynaturalizm nigdy nie były też składnikami żadnego znaczącego kryterium demarkacji. Jeśli weryfikacjoniści i falsyfikacjoniści mogą być zarówno nadnaturalistami, artyficjalistami, jak i naturalistami,

to wynika z tego, że przyjmowany przez nich „na początku” naturalizm bądź nadnaturalizm nie jest składnikiem kryterium demarkacji. ${ }^{5}$

Warto $\mathrm{w}$ tym miejscu nadmienić, że zarówno $\mathrm{w}$ ramach naturalizmu, jak i ujęć względem niego alternatywnych, na ogół rozumiana po Popperowsku, falsyfikowalność (z teorii należy zrezygnować, gdy w ramach ujęcia alternatywnego przyjęto niezgodne $\mathrm{z}$ nią stwierdzenia bazowe) ${ }^{6}$ jest powszechnie akceptowalnym kryterium naukowości. ${ }^{7}$

uz.zgora.pl/images/Przedruki/Bylica_Wspolczesny.teizm.naturalistyczny.pdf (16.01.2018).

${ }^{4}$ Por. Dariusz SAGAN, „Kazimierz Jodkowski o teorii inteligentnego projektu”, w: BYLICA, Kilian, Piotrowski i Sagan (red.), Filozofia - nauka - religia..., s. 217 [213-227], http://www. nauka-a-religia.uz.zgora.pl/images/Przedruki/Sagan_Kazimierz.Jodkowski.o.teorii.ID.pdf (18.01. 2018).

${ }^{5}$ Kazimierz JodKowski, „Kreacjoniści przed sądem. Aspekty filozoficzne «małpich procesów»”, w: Jakub Michalczenia, Jadwiga Mizińska i Katarzyna Ossowska (red.), Poszukiwania filozoficzne. Tom I: Nauka, Prawda. Panu Profesorowi Józefowi Dębowskiemu w darze, Instytut Filozofii Uniwersytetu Warmińsko-Mazurskiego w Olsztynie, Olsztyn 2014, s. 177 [175-198], www.nauka-a-religia.uz.zgora.pl/images/Przedruki/Jodkowski_Kreacjonisci.przed.sadem.Aspekty .filozoficzne.malpich.procesow.pdf (02.01.2018).

${ }^{6}$ Jest to jedna z wersji Popperowskiego falsyfikacjonizmu. W sprawie ewolucji poglądów Poppera por. np. Imre LAKATOs, „Falsyfikacja a metodologia naukowych programów badawczych", w: Imre LaKatos, Pisma z filozofii nauk empirycznych, przeł. Wojciech Sady, Biblioteka Współczesnych Filozofów, Wydawnictwo Naukowe PWN, Warszawa 1995, s. 10-71 [3-169]; Kazimierz JodKowsкi, „Falsyfikacjonizm a wzrost wiedzy”, Annales UMCS 1977, Sec. I, Philosophia-Sociologia, vol. 2, s. 257 [255-272]; Kazimierz JODKOWSKI, Wspólnoty uczonych, paradygmaty i rewolucje naukowe, Realizm. Racjonalność. Relatywizm, t. 22, Wydawnictwo UMCS, Lublin 1990, s. 51; Artur KoтеRsкI, Falsyfikacjonistyczne kryteria demarkacji w XX-wiecznej filozofii nauki, Wydawnictwo UMCS, Lublin 2004, s. 17-24, 55-89, 191-217.

${ }^{7}$ Por. np. Michael J. BeHE, „Filozoficzne zarzuty stawiane hipotezie inteligentnego projektu: odpowiedź na krytykę", przeł. Dariusz Sagan, Filozoficzne Aspekty Genezy 2004, t. 1, s. 119 [115139], http://www.nauka-a-religia.uz.zgora.pl/images/FAG/2004.t.1/art.02.pdf (03.02.2018); Robert T. PENNock, „Bóg w lukach wiedzy: argument z niewiedzy i ograniczenia naturalizmu metodologicznego”, przeł. Dariusz Sagan, Filozoficzne Aspekty Genezy 2012, t. 9, s. 174, 176-177 [155-185], http://www.nauka-a-religia.uz.zgora.pl/images/FAG/2012.t.9/art.04.pdf (03.02.2018); Taner EDIS, „Dlaczego «teoria inteligentnego projektu» jest bardziej interesująca niż tradycyjny 
Uznanie jakiegoś nakazu za warunek sine qua non ma daleko idące następstwa. Staje się on definicyjnym składnikiem nauki. ${ }^{8}$ Akceptacja taka jest równoznaczna $\mathrm{z}$ apriorycznym wykluczaniem możliwych, alternatywnych sposobów wyjaśniania rzeczywistości. ${ }^{9}$ Przykładowo zwolennicy naturalizmu metodologicznego utrzymują, że:

koniecznym warunkiem, jeśli chcemy pozostać w sferze nauki, [jest przyjęcie, że] [...]

kreacjonizm”, przeł. Dariusz Sagan, Filozoficzne Aspekty Genezy 2007/2008, t. 6/7, s. 82 [81-93], http://www.nauka-a-religia.uz.zgora.pl/images/FAG/2007-2008.t.4-5/art.08.pdf (04.02.2018); Dariusz SAGAN, Metodologiczno-filozoficzne aspekty teorii inteligentnego projektu, Biblioteka Filozoficznych Aspektów Genezy, t. 6, Instytut Filozofii Uniwersytetu Zielonogórskiego, Zielona Góra 2015, s. 54, 233-235, 278-280, www.nauka-a-religia.uz.zgora.pl/images/Przedruki/Sagan Metodologiczno-filozoficzne.aspekty.ID.pdf (04.02.2018); Massimo Pigliucci, Tales of the Rational: Skeptical Essays About Nature and Science, Freethought Press, Atlanta, Georgia 2000, s. 21; Robert A. Delfino, „Naturalizm metodologiczny i ewolucja”, przeł. Rafał Lizut, w: Piotr JaroszyŃSKI (red.), Ewolucjonizm czy kreacjonizm, Przyszłość Cywilizacji Zachodu, Fundacja „Lubelska Szkoła Filozofii Chrześcijańskiej”, Lublin 2008, s. 154 [137-156].

Zauważa się również, że tak rozumiana falsyfikacja nie ma charakteru definitywnego (por. np. William A. Dembsкi, The Design Revolution: Answering the Toughest Questions about Intelligent Design, InterVarsity Press, Downers Grove, Illinois 2004, s. 281; Delfino, „Naturalizm metodologiczny i ewolucja...”, s. 153-154).

${ }^{8}$ Por. Kazimierz Jodkowski, „Rozpoznawanie genezy: istota sporu ewolucjonizm-kreacjonizm”, Roczniki Filozoficzne 2002, t. 50, z. 3, s. 189 [187-198], www.nauka-a-religia.uz.zgora. pl/images/Przedruki/Jodkowski_Rozpoznawanie.genezy.pdf (12.02.2018); Kazimierz JoDKowski, „Twarde jądro ewolucjonizmu”, Roczniki Filozoficzne 2003, t. 51, z. 3, s. 85 [77-117], www.na uka-a-religia.uz.zgora.pl/images/Przedruki/Jodkowski_Twarde.jadro.ewolucjonizmu.pdf $\quad$ (12.02. 2018); Kazimierz JodKowsKI, „Kłopoty teistycznego ewolucjonizmu”, w: Grzegorz BugaJAK i Jacek ТомсZук (red.), Kontrowersje wokól początków czlowieka, Księgarnia św. Jacka, Katowice 2007, s. 218 [209-224], www.nauka-a-religia.uz.zgora.pl/images/Przedruki/Jodkowski Klopoty. teistycznego.ewolucjonizmu.pdf (31.01.2018); Piotr ByLICA, „Naturalizm metodologiczny jako warunek naukowości w kontekście relacji nauki i religii”, Przeglą Filozoficzny - Nowa Seria 2004, R. 13, nr 3 (51), s. 164-165 [163-175], www.nauka-a-religia.uz.zgora.pl/images/Przedruki/ Bylica Naturalizm.metodologiczny.jako.warunek.naukowosci.pdf (01.02.2018); Piotr BYLICA, „Zaburzenia dysocjacyjne czy opętanie przez Szatana. Historyczno-metodologiczna analiza stosunku psychiatrii do problemu opętań”, w: ZoN (red.), Pogranicza nauki..., s. 218-219 [209-225], www.nauka-a-religia.uz.zgora.pl/images/Przedruki/Bylica_Zaburzenia.dysocjacyjne.pdf $\quad(01.02$. 2018); Piotr Bylica and Dariusz SAGAN, „God, Design, and Naturalism: Implications of Methodological Naturalism in Science for Science-Religion Relation”, Pensamiento 2008, vol. 64, núm. 242, s. 622 [621-638], http://www.nauka-a-religia.uz.zgora.pl/images/Przedruki/Bylica.Sagan God.Design.and.Naturalism.pdf (31.01.2018).

${ }^{9}$ Por. np. wypowiedź Kazimierza Jodkowskiego w: Willma, „Przyroda, Bóg, nauka...”, s. 7; 
życie powstało spontanicznie poprzez procesy naturalne. ${ }^{10}$

Dowolna nauka może istnieć tylko pod warunkiem przyjęcia założenia, że Bóg nie interweniuje w przebieg zjawisk, i sprawdzenia, jak daleko można się posunąć w ich wyjaśnianiu. ${ }^{11}$

Uczonym wolno formułować tylko takie idee, które odnoszą się do materialnego wszechświata, a mogą je formułować tylko w taki sposób, który pozwala na ich testowanie za pomocą świadectw empirycznych wykrywalnych dla naszych zmysłów. ${ }^{12}$

Jeśli w ogóle istnieje jakiekolwiek kryterium, na mocy którego uznaje się jakąś idę za naukową, to jest nim właśnie nakaz odwoływania się do naturalistycznych wyjaśnień zjawisk, a wyjaśnienia te muszą być testowalne wyłącznie w oparciu o nasze zmysły. ${ }^{13}$

W nauce nigdy nie wolno rezygnować z wyjaśnienia jakiegoś „,materialnego zjawiska” przy pomocy innego „materialnego zjawiska”. Rezygnacja z takiego wyjaśnienia i powołanie się na wyjaśnienie „wychodzące poza świat materialny” byłoby zablokowaniem dalszego postępu, a więc sprzeniewierzeniem się naukowej metodzie. ${ }^{14}$

JodKowskI, „Nienaukowy fundament nauki...”, s. 95-96; Dariusz SAGAN, „Naturalizm metodologiczny — konieczny warunek naukowości?”, Roczniki Filozoficzne 2013, t. LXI, nr 1, s. 75, 83 [73-91], www.nauka-a-religia.uz.zgora.pl/images/Przedruki/Sagan_Naturalizm.metodologiczny.k onieczny.warunek.naukowosci.pdf (18.01.2018)

${ }^{10}$ Christian DE Duve, „The Beginning of Life on Earth”, American Scientist 1995, vol. 83, s. 428 [428-437], http://pratclif.com/memes/deduve-begin-life1.html (07.02.2018). Por. też Kazimierz JoDKоwsкI, Metodologiczne aspekty kontrowersji ewolucjonizm-kreacjonizm, Realizm. Racjonalność. Relatywizm, t. 35, Wydawnictwo UMCS, Lublin 1998, s. 292; Piotr ByLICA, „Spór o naukowość teorii inteligentnego projektu”, w: Kazimierz JoDKowsKI (red.), Teoria inteligentnego projektu - nowe rozumienie naukowości?, Biblioteka Filozoficznych Aspektów Genezy, t. 2, Wydawnictwo MEGAS, Warszawa 2007, s. 62-63 [51-78], http://www.nauka-a-religia.uz.zgora. pl/images/Przedruki/Jodkowski_red._Teoria.ID.nowe.rozumienie.naukowosci.pdf (20.01.2018).

${ }^{11}$ Steven Weinberg, Sen o teorii ostatecznej, przeł. Piotr Amsterdamski, Alkazar, Warszawa 1994, s. 312

${ }^{12}$ Niles Eldredge, The Triumph of Evolution and the Failure of Creationism, W.H. Freeman and Company, New York 2001, s. 137.

${ }^{13}$ Niles Eldredge, The Monkey Business: A Scientist Looks at Creationism, Washington Square Press, New York 1982, s. 82, fragment w przekładzie Piotra BYLıcy, „Konflikt między teizmem i nauką bazującą na naturalizmie - w ujęciu Phillipa E. Johnsona”, Zagadnienia Naukoznawstwa 2003, nr 3-4, s. 227 [227-238], www.nauka-a-religia.uz.zgora.pl/images/Przedruki/Byli ca_Konflikt.miedzy.teizmem.i.nauka.pdf (02.01.2018). Por. też Leonard BRAND, „Naturalizm i jego rola w nauce", przeł. Paulina Korzeniewska-Nowakowska, Filozoficzne Aspekty Genezy 2016, t. 13, s. 56-57 [49-74], www.nauka-a-religia.uz.zgora.pl/images/FAG/2016.t.13/art.11.pdf (02.01. 2018).

${ }^{14}$ Michał Heller, Sens życia i sens Wszechświata. Studia z teologii wspólczesnej, Biblos, Tarnów 2002. Por. też Piotr Bylica, „Nauka światopoglądowo neutralna?”, Fronda 2012, nr 63, 
Jednakże, jak zauważono, uznanie jakiegoś nakazu za konieczny warunek uprawiania nauki nie ma charakteru ostatecznego. W tej sprawie zgodni są filozofowie ${ }^{15}$ i uczeni. ${ }^{16}$

Dla artyficjalistycznego EUO sformułowano mocne, aprioryczne kryterium, na mocy którego można odstąpić od wyjaśnień nienaturalistycznych. ${ }^{17}$ Wystarczy podać kontrprzykład dla tezy: nie istnieje naturalna przyczyna, która jest w stanie wytworzyć nieredukowalną lub wyspecyfikowaną złożoność. ${ }^{18}$ Wnioskowanie o inteligentnej przyczynie na podstawie nieredukowalnej złożoności

s. 75 [67-80], www.nauka-a-religia.uz.zgora.pl/images/Przedruki/Bylica_Nauka.swiatopogladowo .neutralna.pdf (28.12.2017)

${ }^{15}$ Por. np. Robert A. Delfino, „Replacing Methodological Naturalism”, Metanexus 24 May 2007, http://www.metanexus.net/essay/replacing-methodological-naturalism (05.02.2018); William A. Dembski, „Odmiany naturalizmu. Czy któraś forma naturalizmu jest zgodna z teorią inteligentnego projektu?", przeł. Dariusz Sagan, Na Początku... 2005, R. 13, nr 1-2, s. 47 [45-54], http:/tiny.pl/xhkg8 (05.02.2018); Del Ratzsch, Science \& Its Limits: The Natural Sciences in Christian Perspective, InterVarsity Press, Downers Grove, Illinois 2000, s. 105.

${ }^{16}$ Por. Weinberg, Sen o teorii ostatecznej..., s. 312; Pigliucci, Tales of the Rational..., s. 21; Dariusz SAGAN, „Naturalizm metodologiczny a zagadnienie prawdy w nauce”, w: Andrzej L. Z $Z_{A-}$ CHARIASz (red.), Poznanie a prawda, Wydawnictwo Uniwersytetu Rzeszowskiego, Rzeszów 2009, s. 172-173 [167-173], www.nauka-a-religia.uz.zgora.pl/images/Przedruki/Sagan_Naturalizm.meto dologiczny.a.prawda.pdf (21.01.2018); BYLICA, „Naturalizm metodologiczny jako warunek naukowości...”, s. 167.

${ }^{17}$ Por. SAgan, Metodologiczno-filozoficzne aspekty..., s. 45-47; Michael J. BeHE, Czarna skrzynka Darwina. Biochemiczne wyzwanie dla ewolucjonizmu, przeł. Dariusz Sagan, Biblioteka Filozoficznych Aspektów Genezy, t. 4, Wydawnictwo MEGAS, Warszawa 2008, s. 274.

${ }^{18}$ Pojęcie układu nieredukowalnie złożonego wprowadził Michael Behe:

[Jest to] [...] pojedynczy system złożony z poszczególnych dobrze dopasowanych, oddziałujących ze sobą części, które mają udział w pełnieniu podstawowej funkcji układu. Usunięcie jakiejkolwiek z tych części powoduje, że system przestaje sprawnie funkcjonować.

Michael J. BeHE, „Nieredukowalna złożoność: problem dla ewolucjonizmu darwinowskiego”, przeł. Dariusz Sagan, Filozoficzne Aspekty Genezy 2005/2006, t. 2/3, s. 68-69 [67-96], www. nauka-a-religia.uz.zgora.pl/images/FAG/2005-2006.t.2-3/art.01.pdf (12.01.2018). Układ ten, zdaniem Behe'ego, nie mógł wyewoluować w gradualistycznym procesie darwinowskim, ponieważ nie mogły istnieć żadne, pełniące taką samą funkcję, układy poprzedzające, z których mógłby się rozwinąć. Najczęściej przytaczane przykłady układów nieredukowalnie złożonych to: wić bakteryjna, rzęska eukariotyczna, kaskada krzepnięcia krwi, transport wewnątrzkomórkowy oraz sys tem immunologiczny (por. Behe, Czarna skrzynka Darwina..., s. 43-44; SAgan, Metodolo-

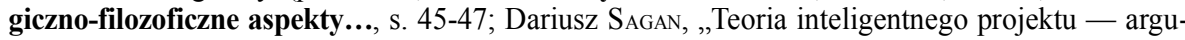
menty za i przeciw”, w: Stanisław JaneczeK, Anna Starościc, Dariusz DąBeK i Justyna Herda 
należałoby zakwestionować wtedy, gdy udałoby się wykazać, że mechanizm darwinowski jest w stanie wytworzyć układ o określonym stopniu złożoności (przykładowo wić bakteryjną, składającą się z około 50-ciu rodzajów białek) nic nie stoi wtedy na przeszkodzie, by twierdzić, że mechanizm ten może wytworzyć dowolny system o mniejszym, równym lub większym stopniu złożoności. ${ }^{19}$ Natomiast wnioskowanie o inteligentnej przyczynie na podstawie wyspecyfikowanej złożoności należałoby zakwestionować wtedy, gdy udałoby się wy-

(red.), Filozofia przyrody, Dydaktyka Filozofii, t. III, Wydawnictwo Katolickiego Uniwersytetu Lubelskiego, Lublin 2013, s. 337-338 [335-383], www.nauka-a-religia.uz.zgora.pl/images/Przed ruki/Sagan_Teoria.ID.argumenty.za.i.przeciw.pdf (02.01.2018); Dariusz SAGAN, „Ewaluacja ewolucjonistycznych rozwiązań problemu nieredukowalnej złożoności”, Otwarte Referarium Filozoficzne 2009, t. 2, Genesis. Filozoficzne konsekwencje wyników badań przyrodniczych o początku świata, życia, człowieka, s. 90-95 [89-116], www.nauka-a-religia.uz.zgora.pl/images/Przedruki/Sa gan_Ewaluacja.ewolucjonistycznych.rozwiazan.problemu.IC.pdf (23.01.2018).

Pryncypialną krytykę takiego ujęcia odnaleźć można u Marka PeraKHA, „Nieredukowalna sprzeczność”, przeł. Dariusz Sagan, Filozoficzne Aspekty Genezy 2004, t. 1, s. 95-105 [71-113], www.nauka-a-religia.uz.zgora.pl/images/FAG/2004.t.1/art.04.pdf (28.01.2018). Przegląd innych ważniejszych głosów krytycznych względem tej kategorii odnaleźć można w artykule Roberta T. PEnNocka, „Creationism and Intelligent Design”, Annual Review of Genomics and Human Genetics 2003, vol. 4, s. 153-154 [143-163], http://bio.classes.ucsc.edu/bio175/Other/Pennock_2003. $\operatorname{pdf}(19.01 .2018)$.

Pojęcie wyspecyfikowanej złożoności wywodzi się od Williama Dembskiego. Złożoność ta jest cechą zjawisk, które z perspektywy wyjaśnień naturalistycznych mają bardzo małe prawdopodobieństwo. Do wykrycia zjawisk charakteryzujących się taką złożonością używa się tak zwanego „filtra ekplanacyjnego”, intelektualnego narzędzia, za pomocą którego odróżnić można skut ki działania przyczyn inteligentnych od skutków działań przyczyn nieinteligentnych. Filtr ten jest użyteczny w sytuacjach, gdy można poddać analizom jedynie zaprojektowany obiekt i nie ma się styczności z procesem projektowania (por. Dariusz SAGAN, „Filtr eksplanacyjny: wykrywanie inteligentnego projektu na gruncie nauk przyrodniczych”, Roczniki Filozoficzne 2009, t. LVII, nr 1, s. 158-167 [157-193], www.nauka-a-religia.uz.zgora.pl/images/Przedruki/Sagan_Filtr.eksplanacyj

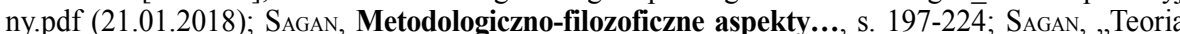
inteligentnego projektu - argumenty za i przeciw...”, s. 338-339; Piotr BYLICA, „Testowalność teorii inteligentnego projektu", Filozofia Nauki 2003, R. XI, nr 2(42), s. 43-47 [41-49], www.na uka-a-religia.uz.zgora.pl/images/Przedruki/Bylica Testowalnosc.teorii.ID.pdf (04.02.2018). Przegląd innych ważniejszych głosów krytycznych względem tej kategorii odnaleźć można w artykule PennockA, „Creationism and Intelligent Design...”, s. 154-155.

${ }^{19}$ Por. SAGan, Metodologiczno-filozoficzne aspekty..., s. 47, 269-286; PEnNock, „Bóg w lukach wiedzy...”, s. 174; EdIs, „Dlaczego «teoria inteligentnego projektu»...”, s. 82. Przeciwnego zdania jest Coyne, który twierdzi, że

takiej teorii nie można sfalsyfikować, ponieważ za każdym razem, gdy jakiś proces bioche- 
kazać, że procesy naturalne wytwarzają ową złożoność. ${ }^{20} \mathrm{~W}$ obydwu powyższych warunkach widoczne jest podejście charakterystyczne dla wyrafinowanej postaci falsyfikacjonizmu:

Jest najzupełniej możliwe, że teorie formułowane są w sposób „postępowy” w takiej kolejności, że „obalenia” $n$-tej pojawiają się wyłącznie jako potwierdzenia $(n+1)$-tej. ${ }^{21}$

Jak w obliczu takich prób „obaleń” zachowaliby się zwolennicy artyficjalizmu, to kwestia, o której rozstrzygnięciu przekonać się można jedynie post factum. Nie da się z góry wykluczyć tego, że ich działania nie odbiegałyby od standardowych, obronnych zachowań innych wspólnot uczonych, których teoria znalazła się w tarapatach. ${ }^{22}$ Przykładem takich zachowań jest tłumienie świa-

miczny uzyska wyjaśnienie ewolucyjne, Behe łatwo może zawęzić dziedzinę Projektanta do procesów jeszcze niewyjaśnionych.

Jerry A. Coyne, „Nowa fala fanatyzmu w nauce”, przeł. Dariusz Sagan, Filozoficzne Aspekty Genezy 2004, t. 1, s. 51 [49-53], http://www.nauka-a-religia.uz.zgora.pl/images/FAG/2004.t.1/art. 01.pdf (02.02.2018).

Coyne utrzymuje swoją tezę mimo tego, że Behe odwołuje się do konkretnych przykładów, z których wystarczy sfalsyfikować jeden, by pozostałe można było uznać za możliwe do wytworzenia przez mechanizm darwinowski (por. BeHE, „Filozoficzne zarzuty...”, s. 119). Por. też Discovery Institute, „Falsyfikowalność teorii inteligentnego projektu”, przeł. Dariusz Sagan, Na Początku ... 2005, nr 11-12A (200-201), s. 455-457 [455-457], www.nauka-a-religia.uz.zgora.pl/ima ges/Przedruki/Discovery.Institute Falsyfikowalnosc.teorii.ID.pdf (12.02.2018); Dariusz SAGAN, „Zarzut nietestowalności teorii inteligentnego projektu”, Studia Philosophica Wratislaviensia 2013, vol. VIII, fasc. 3, s. 43 [43-59], www.nauka-a-religia.uz.zgora.pl/images/Przedruki/Sagan Zarzut.nietestowalnosci.teorii.ID.pdf (13.02.2018); BYLICA, „Testowalność teorii inteligentnego projektu...", s. 48-49; wypowiedź Krzysztofa J. Kiliana w: Piotr BylicA, Kazimierz JodKowski, Krzysztof J. KiLIAN i Dariusz SAGAn, „Dyskusja nad artykułem Adama Groblera, «Słabości eksplanacyjne teorii inteligentnego projektu»”, Filozoficzne Aspekty Genezy 2013, t. 10, s. 28 przyp. 17 [17-63], www.nauka-a-religia.uz.zgora.pl/images/FAG/2013.t.10/art.14.pdf (13.02.2018).

${ }^{20}$ Por. SAGAN, Metodologiczno-filozoficzne aspekty..., s. 54, 233-235, 278-280; PENNOCK, „Bóg w lukach wiedzy...”, s. 176-177.

${ }^{21}$ LaKatos, „Falsyfikacja a metodologia...”, s. 53 [wyróżnienie w oryginale]. Por. też Wojciech SADY, „Czego Kazimierz Jodkowski nie dostrzega, jeśli o odkrycia naukowe chodzi?”, w: Bylica, Kilian, Piotrowski i Sagan (red.), Filozofia - nauka - religia..., s. 60 [59-64]; wypowiedź Paula K. Feyerabenda, w: Renato Parascandalo and Vittorio HösLE, ,,Three Interviews with Paul K. Feyerabend”, Teleos: A Quarterly Journal of Critical Thought 1995, no. 102, s. 119 [115$148]$.

${ }^{22}$ Por. np. Thomas S. Kunn, „The Function of Dogma in Scientific Research”, w: Alistair Cameron Crombie (ed.), Scientific Change: Historical Studies in the Intellectual, Social and 
dectwa. Zjawisko tłumienia świadectwa, najogólniej rzecz biorąc, polega na odrzucaniu takich wyników, które są niezgodne $\mathrm{z}$ powszechnie przyjmowanym punktem widzenia. Na ogół argumentuje się w ten sposób, że rozwiązania tego typu bazują na fałszywych (czyli, de facto, niezgodnych z aktualnie obowiązującym poglądem) przesłankach. Redakcje czasopism naukowych odmawiają wtedy publikowania prac zawierajacych tezy niezgodne z przyjętym sposobem wyjaśniania. ${ }^{23}$ Tłumienie świadectwa jest jednym $\mathrm{z}$ elementów tak zwanych „wybiegów konwencjonalistycznych", przed którymi przestrzegał Popper. Jego zdaniem uczony nie powinien immunizować teorii w obliczu jej niezgodności z doświadczeniem, czyli: używać hipotez ad hoc; modyfikować definicji ostensywnych terminów merytorycznych $\mathrm{w}$ sytuacji niezgodności teorii $\mathrm{z}$ doświadczeniem; watpić w rzetelność wyników uzyskanych przez eksperymentatora lub też odrzucać wyników badań z powodów wyżej wspomnianych. ${ }^{24}$

Dla naturalistycznych EUO ich zwolennicy nie sformułowali żadnego mocnego, kryterium, na mocy którego można by odstapić od wyjaśnień naturalistycznych, choć przyznaje się, że „falsyfikacja paradygmatu naturalistycznego jest możliwa". ${ }^{25}$

Technical Conditions for Scientific Discovery and Technical Invention, from Antiquity to the Present, Symposium on the History of Science, University of Oxford 9-15 July 1961, Heinemann, London 1963, s. 348-349 [347-369]; Dariusz SAGAN, ,Spór o możliwość wykrywania projektu w naukach przyrodniczych", Scientia et Fides 2015, vol. 3, nr 1, s. 96 [87-113], www.nau ka-a-religia.uz.zgora.pl/images/Przedruki/Sagan Spor.o.mozliwosc.wykrywania.projektu.pdf (12. 02.2018); Dariusz SAGAN, „Molekularny «zegar Paleya» a darwinowska ewolucja”, Ruch Filozoficzny 2005, t. LXII, nr 2, s. 289-295, 301 [289-304], www.nauka-a-religia.uz.zgora.pl/images/Prz edruki/Sagan_Molekularny.zegar.Paleya.pdf (12.02.2018).

${ }^{23}$ Por. Thomas S. KunN, Struktura rewolucji naukowych, przeł. Helena Ostromęcka i Justyna Nowotniak, Aletheia, Warszawa 2001, s. 48; Michael PolanYI, „The Republic of Science: Its Political and Economic Theory”, Minerva 2000, vol. 38, s. 8-9, 16-17 [1-32] (przedruk z: „Minerva" 1962, vol. 1, s. 54-73); JoDKowsKi, Wspólnoty uczonych..., s. 152, 302-303.

${ }^{24}$ Por. Karl R. Popper, Logika odkrycia naukowego, przeł. Urszula Niklas, Państwowe Wydawnictwa Naukowe, Warszawa 1979, s. 70). Termin „immunizacja teorii” wywodzi sie od Hansa Alberta (por. Karl R. Popper, „Wiedza hipotetyczna. Moje rozwiązanie problemu indukcji”, w: Karl R. POPPER, Wiedza obiektywna. Ewolucyjna teoria epistemologiczna, przeł. Adam Chmielewski, Wydawnictwo Naukowe PWN, Warszawa 1992, s. 48 [9-49]).

${ }^{25}$ Pigliucci, Tales of the Rational..., s. 21. Por. też Delfino, „Naturalizm metodologiczny i ewolucja...”, s. 154; Thomas NAGeL, „Public Education and Intelligent Design”, Philosophy \& Public Affairs 2008, vol. 36, no. 2, s. 189 [187-205]. 
Kryterium, w myśl którego, naturalizm metodologiczny jest założeniem roboczym, z którego należy zrezygnować, gdy zacznie ono zawodzić, ${ }^{26}$ jest bardzo słabe. Oto przykład zastosowania tego kryterium:

ograniczenie nauki do sfery naturalnej powinno być przeprowadzone prowizorycznie i opierać się na wcześniejszych niepowodzeniach wyjaśnień nadnaturalistycznych i sukcesach wyjaśnień naturalistycznych. ${ }^{27}$

Tak sformułowane kryterium dopuszcza stan rzeczy, zgodnie z którym, gdy sytuacja ulegnie zmianie i wyjaśnienia nadnaturalistyczne zaczną odnosić sukcesy, a naturalistyczne - porażki, będzie można przyjąć te pierwsze. Jednak sukces jest kategorią, która nie ma charakteru neutralnego. Przykładowo jeden ze zwolenników wyjaśnień naturalistycznych stwierdził, iż

ostatnie lata przyniosły szereg ważnych wyników [...] [świadczących o tym], że życie powstało w drodze spontanicznych procesów. ${ }^{28}$

Zaś jeden z przeciwników dominacji takich wyjaśnień doszedł do wniosku, iż błędnie się

sądzi, że symulacyjne eksperymenty Millera i inne podobne typy eksperymentów stanowią mocne empiryczne poparcie dla naturalistycznego pochodzenia życia. ${ }^{29}$

Nie da się również wyznaczyć limitu czasowego tolerowania niepowodzeń jakiegoś sposobu wyjaśniania. Nie istnieją środki, za pomocą których z góry można orzec, że krytykowany punkt widzenia nie może zostać rozwinięty tak,

\footnotetext{
${ }^{26}$ Por. SAGAN, „Naturalizm metodologiczny a zagadnienie prawdy w nauce...”, s. 168-169; SAGAN „Naturalizm metodologiczny — konieczny warunek naukowości...”, s. 77; Delfino, „Naturalizm metodologiczny i ewolucja...", s. 154; PIgliucci, Tales of the Rational..., s. 21.

${ }^{27}$ Por. Erkki V.R. KoJonen, „Methodological Naturalism and the Truth Seeking Objection”, International Journal for Philosophy of Religion 2016, vol. 79, no. 3, s. 3 [1-26], http://blogs.hel sinki.fi/ekojonen/files/2015/10/Methodological-naturalism-and-the-truth-seeking-objection-Kojon en-1.pdf(12.02.2018).

${ }^{28}$ January WeINER, „Hipotezy o powstaniu i wczesnej ewolucji życia. Historia dociekań (od Darwina do Millera)", Kosmos 2009, t. 58, nr 3-4, s. 502 [501-528], http://kosmos.icm.edu.pl/ PDF/2009/501.pdf (31.01.2018).

${ }^{29}$ Dean H. KenYon, „Kreacjonistyczne ujęcie pochodzenia życia”, przeł. Kazimierz Jodkowski, w: JoDKowsкi, Metodologiczne aspekty..., s. 486 [482-495].
} 
aby był w stanie stawić czoło największym trudnościom. ${ }^{30}$ Nie wszyscy krytycy naturalizmu zdają sobie $\mathrm{z}$ tego sprawę:

Za trzydzieści lat będziemy w zupełnie innej sytuacji. Dowody płynące z nauki są po prostu tak mocne, że darwinizm nie może przetrwać. ${ }^{31}$

Chociaż trudno przewidzieć (często nieliniowy) postęp nauki, jego kierunek wskazuje, że im więcej wiemy, tym łatwiej dostrzegamy projekt. Spodziewam się, że w najbliższych dekadach pogląd głoszący, iż przyroda jest tworem przypadku, będzie coraz bardziej zanikał. Stale będziemy wyrokowali o projekcie i przypadkowości dzięki bazie teoretycznej, jaką daje nam praca Billa Dembskiego. ${ }^{32}$

Istnieje też inne wyjaśnienie dla śmiałości takich przewidywań: „takie narracje retoryczne są charakterystyczne dla całego Ruchu ID”. Wytwarzanie przewidywań tego typu jest świadomym działaniem, mającym na celu wzbudzanie atmosfery kryzysu w stosunku do krytykowanego ujęcia. ${ }^{33}$

Śmiałość przewidywań, warto tu nadmienić, charakteryzuje nie tylko przeciwników naturalizmu metodologicznego:

${ }^{30}$ Por. np. Paul K. Feyerabend, „Ku pocieszeniu specjalisty”, w: Paul K. Feyerabend, Jak być dobrym empirystą, przeł. Krystyna Zamiara, PWN, Warszawa 1979, s. 207-208 [200-250].

${ }^{31}$ Wypowiedź Jaya W. Richardsa w: Michał CHABEREK OP, „Neodarwinizm skończy jak marksizm. Rozmowa z Jay'em W. Richardsem”, Fronda 2012, nr 63, s. 46 [43-47].

${ }^{32}$ Fragment „Przedmowy” Michaela J. Behe'ego do książki Williama Dembskiego, Intelligent Design: The Bridge between Science and Theology, InterVarsity Press, Downers Grove, Illinois 1999, przytaczam za: PeraKH, „Nieredukowalna sprzeczność...”, s. 84.

W innym miejscu Behe wypowiedział się już w sposób bardziej stonowany:

Jesteśmy u samego początku zmiany paradygmatu w biologii i nikt tak naprawdę nie wie, czym to się skończy.

Wypowiedź Michaela Behe'ego w: Mark RyLand, „«Teoria inteligentnego projektu» podważa teorię ewolucji. Już sama złożoność stworzenia świadczy o działaniu siły wyższej. Darwinizm? Nie ma szans. Wywiad z Michaelem J. Behe'em dla Our Sunday Visitor", przeł. Dariusz Sagan, Na Poczatku... 2004, nr 11-12A (187-188), s. 420 [414-420], www.nauka-a-religia.uz.zgora.pl/im ages/Przedruki/Ryland_Teoria.ID.podwaza.teorie.ewolucji.pdf (31.01.2018).

${ }^{33}$ Por. Dariusz SAGAN, „Retoryczna historia Ruchu Inteligentnego Projektu”, Diametros 2005, nr 4, s. 81 [76-85], www.nauka-a-religia.uz.zgora.pl/images/Przedruki/Sagan_Retoryczna.historia .Ruchu.ID.pdf (07.02.2018). 
Zbliżamy się do czasów, kiedy uzyskamy naukowy wgląd w fizyczne determinanty ludzkich zachowań, a przede wszystkim w proces generowania wartości przez człowieka. Poznamy ten unikalny rezerwuar stanów ludzkiej świadomości, który potocznie nazywamy duszą. ${ }^{34}$

Wracając do kryteriów porzucania naturalizmu, powiedzieć trzeba, że równie słabe są kryteria odwołujące się do wyjaśnienia bardziej przekonującego (z naturalizmu należy zrezygnować, gdy znane jest wyjaśnienie bardziej przekonujące) ${ }^{35}$ lub do dobrego naukowego powodu.

Autor pierwszego argumentu nie formułuje explicite warunków oceny konkurujących hipotez. Zapewne chodzi mu o to, że należy wybierać wyjaśnienia naturalistyczne, gdyż ,wiele domniemanych przypadków inteligentnego projektu okazało się czymś zupełnie innym". ${ }^{36}$ Jego tezę łatwo odwrócić: gdy istnieje bardziej przekonujące nienaturalistyczne wyjaśnienie od znanego wyjaśnienia naturalistycznego, to z tego drugiego należy zrezygnować.

W myśl argumentu drugiego

na tym poziomie biologii nie znajdujemy żadnego dobrego naukowego powodu, by nie wyciągnąć wniosku, że owe mechanizmy [układy cechujące się nieredukowalną złożonością] rzeczywiście zostały zaprojektowane przez jakiś inteligentny czynnik. ${ }^{37}$

\footnotetext{
${ }^{34}$ Wypowiedź Jerzego Lukierskiego na konferencji „Czy nauka zastąpi religię?”, 03-04. 10.2008 UJ, przytaczam za: Anna WoJnAR, „Czy nauka zastąpi religię?”, Alma Mater. Miesięcznik Uniwersytetu Jagiellońskiego 2008, nr 108, s. 92 [91-94], http://www2.almamater.uj.edu.p1/108/ 22.pdf (20.01.2018).

${ }^{35}$ Por. Loren Petrich, „Artefakty zwierzęce i pozaziemskie — inteligentnie zaprojektowane?”, przeł. Dariusz Sagan, Filozoficzne Aspekty Genezy 2009/2010, t. 6/7, s. 152-153 [139153], www.nauka-a-religia.uz.zgora.pl/images/FAG/2009-2010.t.6-7/art.06.pdf (25.01.2018). Por też William B. Provine, „Projekt? Tak! Ale czy inteligentny?”, przeł. Sławomir Piechaczek, Filozoficzne Aspekty Genezy 2005/2006, t. 2/3, s. 223-224, http://www.nauka-a-religia.uz.zgora.pl/ima ges/FAG/2005-2006.t.2-3/art.10.pdf(12.03.2018).

${ }^{36}$ Petrich, ,Artefakty zwierzęce i pozaziemskie...”, s. 153.

${ }^{37}$ Thomas WoODWARD, „Istota sporu darwinizmu z teorią inteligentnego projektu: przyrodnicza symfonia makroewolucji”, przeł. Dariusz Sagan, Filozoficzne Aspekty Genezy 2007/2008, t. 4/5, s. 15 [7-20], http://www.nauka-a-religia.uz.zgora.pl/images/FAG/2007-2008.t.4-5/art.01. pdf (12.03.2018). Por. też Antoni Hoffman, „Wstęp”, w: Richard Dawkins, Ślepy zegarmistrz, czyli jak ewolucja dowodzi, że świat nie zostal zaplanowany, przeł. Antoni Hoffman, Biblioteka Myśli Wspótczesnej, Państwowy Instytut Wydawniczy, Warszawa 1994, s. 9 [5-10].
} 
Tezę tego argumentu również łatwo odwrócić: na tym poziomie biologii nie znajdujemy żadnego dobrego naukowego powodu, by wyciągnąć wniosek, że wyjaśnienia naturalistyczne są wystarczające.

Zauważono też, że

$\mathrm{z}$ tego, że teraz jakichś zjawisk przyrodniczych nie wyjaśnia się zadowalająco przez odwołanie się do procesów naturalnych, nie wynika, że w przyszłości to nie nastąpi. ${ }^{38}$

Sformułowano również kryterium odwołujące się do mocnych kontrświadectw:

naturalizm metodologiczny jest tymczasowym i empirycznie uzasadnionym zobowiązaniem do akceptacji naturalistycznych przyczyn i wyjaśnień, które w zasadzie jest odwoływalne przez nadzwyczajne [przytlaczające i niewątpliwe] świadectwa empiryczne. ${ }^{39}$

I to kryterium nie jest najmocniejsze. Same w sobie świadectwa empiryczne nie są ani przytłaczające, ani niewątpliwe, gdyż tylko od uprzednio przyjętej teorii zależy to, czy świadectwa takie uznane zostaną za istotne. ${ }^{40}$ Zaś nadzwyczajne świadectwa, o ile termin ten rozumiany będzie po Kuhnowsku, ${ }^{41}$ to nic innego niż anomalie. Te ostatnie, wzięte w izolacji, nie podważają przyjętej perspektywy badawczej. Dopiero wtedy,

${ }^{38}$ JoDKowsKi, Metodologiczne aspekty..., s. 313.

${ }^{39}$ Maarten Boudry, Stefaan Blancke, and Johan Braeckman, „How Not to Attack Intelligent Design Creationism: Philosophical Misconceptions About Methodological Naturalism", Foundations of Science 2010, vol. 15, no. 3, s. 227-244. Tekst elektroniczny ma odrębną numerację stron, s. 4 (fragment w nawiasie kwadratowym pochodzi ze s. 17) [1-21], https://biblio.ugent.be/publica tion/956838/file/6828796.pdf (01.10.2017).

${ }^{40}$ Por. np. Kunn, Struktura rewolucji naukowych..., s. 55-64; Paul K. FeYerabend, „Realizm i instrumentalizm. Uwagi o logice potwierdzania przez fakty", w: FeYerabend, Jak być dobrym empirysta...., s. 175-177 [152-193]; Kazimierz JoDKowsKI, „W poszukiwaniu twardego jądra ewolucjonizmu", Filozofia Nauki 2001, nr 2 (34), s. 14 [7-18], www.nauka-a-religia.uz.zgora.pl/ima ges/Przedruki/Jodkowski W.poszukiwaniu.twardego.jadra.ewolucjonizmu.pdf (15.02.2018); wypowiedź Kazimierza Jodk̄owskiego w: Bartosz Borczyk, Adam Chmielewski, Andrzej Elżanowski, Kazimierz Jodkowski, Damian Leszczyński, Jerzy Lukierski, Łukasz Nysler i Bogusław PawŁowski, „Dyskusja”, w: Damian Leszczyński (red.), Ewolucja, filozofia, religia, Lectiones \& Acroases Philosophicae 2010, vol. III, s. 165-166 [155-172], www.nauka-a-religia.uz.zgora.pl/images/Prze druki/Jodkowski_Dyskusja.o.Darwinie.pdf (14.02.2018).

${ }^{41}$ Boudry, Blancke i Braeckman użyli tu nazwy extraordinary empirical evidence. 
gdy grupa specjalistów nie potrafi już unikać anomalii burzących obowiązującą tradycję praktyki naukowej, rozpoczynają się nadzwyczajne badania, w wyniku których zostaje w końcu wypracowany nowy zespół założeń, dostarczający podstawy nowej praktyki badawczej. ${ }^{42}$

Podsumowując, wspólną wadą ostatnich trzech kryteriów jest również to, że uznanie czegoś za dobry naukowy powód lub za wyjaśnienie bardziej przekonujące, albo też za mocne kontrświadectwo, uzależnione jest od akceptowanego EUO. ${ }^{43}$

Brak uniwersalnego, apriorycznego kryterium, na mocy którego można odstąpić od wyjaśnień naturalistycznych, uznawany jest za wadę tego ujęcia. ${ }^{44}$ Moim zdaniem nie jest to wada, lecz zaleta. Wiadomo bowiem, że przestrzeganie apriorycznie nałożonych warunków nie musi prowadzić do sukcesu poznawczego. Zdają sobie z tego sprawę i filozofowie nauki, i uczeni. Wymóg, by uczony przed przystąpieniem do testowania teorii określił z góry warunki, w których zdecyduje się porzucić teorię, uznawany jest za nierealistyczny i bywa ignorowany. ${ }^{45}$

Ponadto, zgodnie z metodologią naukowych programów badawczych, wartościowe programy poddawać należy tymczasowej kwarantannie ad hoc, ${ }^{46}$ pozwolić im na przezwyciężanie trudności, z jakimi się borykają. (Dawno temu zauważono, że „nie istnieje teoria, która zgadza się ze wszystkimi obserwacjami”. ${ }^{47}$ ) Jeśli taki program, w dłuższej perspektywie czasowej, przestaje antycy-

\footnotetext{
${ }^{42}$ KuHN, Struktura rewolucji naukowych..., s. 27.

${ }^{43}$ Por. w tej sprawie komentarz Nagela (NAGeL, „Public Education and Intelligent Design...”, s. 201-202) do procesu Kitzmiller, et al. v. Dover Area School District, et al.

${ }^{44}$ Por. SAGAN, „Naturalizm metodologiczny - konieczny warunek naukowości...”, s. 83; SAGAN, „Naturalizm metodologiczny a zagadnienie prawdy w nauce...”, s. 172-173; ByLICA, „Nauka światopoglądowo neutralna...", s. 75.

${ }^{45}$ Por. np. Paul K. Feyerabend, Zabijanie czasu, przeł. Tomasz Bieroń, Wydawnictwo Znak, Kraków 1996, s. 95; Paul K. Feyerabend, Przeciw metodzie, przeł. Stefan Wiertlewski, Wydawnictwo Siedmioróg, Wrocław 1996, s. 59 przyp. 12.

${ }^{46}$ Por. LaKatos, „Falsyfikacja a metodologia...”, s. 91.

${ }^{47}$ Phillip G. Frank, „The Variety of Reasons for the Acceptance of Scientific Theories”, w: Phillip G. Frank, The Validation of Scientific Theories, The Beacon Press, Boston 1956, s. 3 [328] (cyt. za: Artur KoтеRSкI, Weryfikacjonistyczne kryteria demarkacji w filozofii nauki Kola Wiedeńskiego, Centrum Nauki Języka Angielskiego Metodą Allana, Akces, Poznań 2002, s. 175).
} 
pować nowe fakty, to jego twardy rdzeń (twardy rdzeń gradualistycznego ewolucjonizmu tworzą niepodważalne twierdzenia mówiące o mutacjach, doborze naturalnym i dziedziczeniu ${ }^{48}$ ) powinien, zgodnie $\mathrm{z}$ tą metodologią, zostać porzucony. Zwrócono jednak uwagę, że nawet jeśli wyraźnie wyznaczy się taką perspektywę czasową, to rozwiązanie to również nie ma charakteru rozstrzygającego: bo jeśli pozwala się czekać, to czemu nie poczekać dłużej? ${ }^{49} \mathrm{Nie}$ istnieją środki, za pomocą których wykazać można, że znajdujące się w defensywie ujęcie teoretyczne nie będzie w stanie odnosić sukcesów poznawczych. Nie da się

\footnotetext{
${ }^{48}$ Por. Jodkowski, „Twarde jądro ewolucjonizmu...”, s. 82; Kazimierz JodKowski, „Darwinowska teoria ewolucji jako teoria filozoficzna” w: Stefan KonstańcZaK i Tomasz TurowsKi (red.), Filozofia jako mądrość bycia. Profesorowi Krzysztofowi Kaszyńskiemu w darze z okazji 70. urodzin, Oficyna Wydawnicza Uniwersytetu Zielonogórskiego, Zielona Góra 2009, s. 18 [17-23], www.nauka-a-religia.uz.zgora.pl/images/Przedruki/Jodkowski_Darwinowska.teoria.ewolucji.jako .teoria.filozoficzna.pdf(11.02.2018).

„Twardy rdzeń ewolucjonizmu” — o ile przez „twardy rdzeń” rozumieć się będzie „twierdzenia, których uczony, zwolennik danego programu badawczego, nigdy nie porzuci" — jest pojęciem wieloznacznym. „Twardy rdzeń” oznacza teoretyczne twierdzenia o mutacjach, doborze naturalnym i dziedziczeniu. Oznacza również filozoficzną zasadę naturalizmu, w myśl której „albo Bóg nie działa w świecie przyrody, albo jego działalność jest niewykrywalna metodami empirycznymi” (JodKowski, „Twarde jądro ewolucjonizmu...”, s. 109). Por. też JodKowski, „Darwinowska teoria ewolucji jako teoria filozoficzna...”, s. 19; Kazimierz JodкowsкI, „Metafizyczne opowieści nauki jako fundament pluralizmu naukowego", w: Phillip E. JoHnson, Wielka metafizyczna opowieść nauki (z posłowiem Kazimierza Jodkowskiego), przeł. Piotr Bylica, Archiwum Na Poczatku..., z. 13, Polskie Towarzystwo Kreacjonistyczne, Warszawa 2003, s. 79 [74-85], www.nauka-a-religia.uz.zgora.pl/images/Przedruki/Jodkowski_Metafizyczne.opowiesci.nauki.pdf (13.01.2018); Kazimierz JodKowski, „Uczony w ciemnym budynku. Na marginesie metafory Elżbiety Kałuszyńskiej”, w: Józef DĘBowski i Ewa StarzyŃsKa-Kościuszko (red.), Nauka. Racjonalność. Realizm. Między filozofią przyrody a filozofia nauki i socjologia wiedzy, Instytut Filozofii Uniwersytetu Warmińsko-Mazurskiego w Olsztynie, Olsztyn 2013, s. 63-64 [55-67], www.naukaa-religia.uz.zgora.pl/images/Przedruki/Jodkowski_Uczony.w.ciemnym.budynku.pdf (14.01.2018).

„Twardy rdzeń” oznacza także takie twierdzenia empiryczne, z których ewolucjoniści nie są w stanie zrezygnować. Zauważono, że w tym ostatnim sensie empiryczny twardy rdzeń ewolucjonizmu nie istnieje, gdyż nie istnieje takie twierdzenie empiryczne, z którego ewolucjoniści nie byliby w stanie zrezygnować (por. JоркоwsкI, „Twarde jądro ewolucjonizmu...”, s. 83-84).

${ }^{49}$ Por. Paul K. Feyerabend, „Against Method: Outline of an Anarchistic Theory of Knowledge", w: Michael Radner and Stephen Winokur (eds.), Analyses of Theories and Methods of Physics and Psychology, Minnesota Studies in the Philosophy of Science 1970, vol. 4, s. 77-78 [17-130]; Krzysztof J. Kilian, Poglądy filozoficzne Paula K. Feyerabenda. Część I. Program metodologiczny, Oficyna Wydawnicza Uniwersytetu Zielonogórskiego, Zielona Góra 2014, s. 143 przyp. 637.
} 
też z góry orzec, dokąd zaprowadzą przyszłe badania takiego punktu widzenia. ${ }^{50}$

Podsumowując rozważania o kryteriach odstępowania od wyjaśnień naturalistycznych, zauważyć należy, że istnieje aposterioryczne i stosowalne zarazem kryterium odstąpienia od tego typu wyjaśnień. Dotychczasowa skuteczność zasady metodologicznego naturalizmu pozwala twierdzić, iż

wyjaśnienia naturalistyczne mają priorytet nad ewentualnymi wyjaśnieniami nienaturalistycznymi, że tylko wtedy z tych pierwszych można zrezygnować, jeśli istnieje ku temu dobry powód. ${ }^{51}$

Powód ten nie jest skutkiem braku wiedzy, lecz uzasadniony jest ,już zdobytą wiedzą". ${ }^{52}$

Ten ostatni argument wspierany jest tezą zwaną „warunkiem Jodkowskiego". ${ }^{53}$ Warunek ten

domaga się nie dowodu, ale argumentu, czyli rozumowania, które przy bliższym zbadaniu może się okazać błędne. ${ }^{54}$

W myśl omawianego warunku tam, gdzie wprowadza się wyjaśnienia nienaturalistyczne, należy wprzódy przedstawić mocną argumentację, zgodnie z którą wyjaśnienia naturalistyczne nie są możliwe. ${ }^{55}$ Argumentacja typu:

${ }^{50}$ Por. Grzegorz P. SŁowIK i Krzysztof J. Kilıian, „Hoyle i matematyczne dylematy ewolucjonizmu", w: Bylica, Kilian, Piotrowski i Sagan (red.), Filozofia - nauka - religia..., s. 400-401 [395-408], www.nauka-a-religia.uz.zgora.pl/images/Przedruki/Slowik.Kilian_Hoyle.i.matematycz ne.dylematy.ewolucjonizmu.pdf (19.02.2018).

${ }^{51}$ JodKowski, „Rozpoznawanie genezy...”, s. 190-191.

${ }^{52}$ Por. Jodkowski, Metodologiczne aspekty..., s. 313.

${ }^{53}$ Sprawozdanie z dyskusji nad warunkiem Jodkowskiego przedstawia Małgorzata GAzDA, „Stephena C. Meyera argument na rzecz projektu w przyrodzie a warunek Jodkowskiego”, Filozoficzne Aspekty Genezy 2015, t. 12, s. 287-292 [287-301], http://www.nauka-a-religia.uz.zgora.pl /images/FAG/2015.t.12/art.13.pdf (14.02.2018).

${ }^{54}$ Kazimierz JodKowski, Spór ewolucjonizmu z kreacjonizmem. Podstawowe pojęcia i poglądy, Biblioteka Filozoficznych Aspektów Genezy, t. 1, Wydawnictwo MEGAS, Warszawa 2007, s. 182, http://www.nauka-a-religia.uz.zgora.pl/images/Przedruki/Jodkowski_Spor.ewolucjonizmu. z.kreacjonizmem.pdf (19.01.2018).

${ }^{55}$ Por. JodKowsKI, Metodologiczne aspekty..., s. 313; Wojciech SADY, „Dlaczego kreacjonizm 
żaden [naturalistyczny] mechanizm nigdy nie zostanie odkryty, dzięki czemu pozostanie tylko ta druga alternatywa ${ }^{56}$

uznawana jest za niewystarczającą:

Skutkiem uznania, że [...] został spełniony warunek Jodkowskiego, będzie [...] otrzymanie przepustki do dalszej dyskusji, a nie stwierdzenie słuszności danego argumentu. ${ }^{57}$

Zauważyć też należy, że warunek Jodkowskiego nie wymaga wskazywania na takie dane empiryczne, które mają coś potwierdzać lub czemuś przeczyć. Pozostaje to $\mathrm{w}$ zgodzie $\mathrm{z}$ akceptowanymi w ramach tego ujęcia tezami o mocnym uteoretyzowaniu obserwacji i założeniowości. ${ }^{58}$

W myśl tezy o założeniowości nauka nie może istnieć bez filozoficznych założeń. ${ }^{59}$ Teza ta ma trzy składowe. Zgodnie z pierwszą nauka jako całość przyjmuje wstępne, aprioryczne, często nie wyrażone expressis verbis i przyjmowane

«naukowy» nie jest naukowy i dlaczego nie prowadzi do teizmu?", Przegląd Filozoficzny Nowa Seria 2001, R. X, nr 1 (37), s. 226 [213-228], www.nauka-a-religia.uz.zgora.pl/images/Prze druki/Sady_Dlaczego.kreacjonizm.naukowy.nie.jest.naukowy.pdf (02.02.2018); Kazimierz JoDKowski, „Ruch kreacjonistyczny jest elementem pluralizmu naukowego”, Przeglad Filozoficzny Nowa Seria 2001, R. X, nr 1 (37), s. 246-247 [241-253], www.nauka-a-religia.uz.zgora.pl/im ages/Przedruki/Jodkowski_Ruch.kreacjonistyczny.jest.elementem.pluralizmu.naukowego.pdf (02. 02.2018); JoDKowsKI, Spór ewolucjonizmu z kreacjonizmem..., s. 182-183; wypowiedź Kazimierza Jodkowskiego w: Borczyk, Chmielewski, Elżanowski, Jodkowski, LeszczyŃski, Lukierski, NysLER i PawŁowski, „Dyskusja...”, s. 163-164; Robert Piotrowski, „Kazimierz Jodkowski, Spór ewolucjonizmu z kreacjonizmem. Podstawowe pojęcia i poglądy, Megas, Warszawa 2007 (Biblioteka Filozoficznych Aspektów Genezy, t. 1), ss. 260", Społeczeństwo. Studia. Prace badawcze. Dokumenty z zakresu społecznej nauki Kościoła 2010, R. XX (XVI), nr 1, s. 170-171 [169-172], www.nauka-a-religia.uz.zgora.pl/images/Przedruki/Piotrowski Recenzja.Spor.ewolucjonizmu.z.k reacjonizmem.pdf (15.02.2018).

${ }^{56}$ Pennock, „Bóg w lukach wiedzy...”, s. 170-172.

${ }^{57}$ GAzDA, ,Stephena C. Meyera argument na rzecz projektu w przyrodzie...”, s. 289. Por. też Stephen C. MEYER, „DNA a pochodzenie życia. Informacja, specyfikacja i wyjaśnienie”, przeł. Dariusz Sagan, Filozoficzne Aspekty Genezy 2005/2006, t. 2/3, s. 212 [133-215], http://www.nau ka-a-religia.uz.zgora.pl/images/FAG/2005-2006.t.2-3/art.12.pdf (31.01.2018).

${ }^{58}$ Por. np. wypowiedź Kazimierza Jodkowskiego w: Bylica, Jodkowski, Kilian i Sagan, „Dyskusja nad artykułem Adama Groblera...”, s. 53; Kazimierz Jobkowski, „Curriculum Vitae”, http://www.ifil.uz.zgora.pl/index.php/pl/o-instytucie/zaklad-logiki-i-metodologii-nauk/89-prof-zw -dr-hab-kazimierz-jodkowski (03.02.2018).

${ }^{59}$ Por. Jodkowski, „Curriculum Vitae...”. 
nieświadomie założenia dotyczące natury badanej rzeczywistości oraz dopuszczalnych sposobów jej badania. ${ }^{60} \mathrm{~W}$ myśl drugiej składowej w ramach nauki istnieje możliwość rewizji jej podstawowych założeń. Zgodnie ze składową trzecią w poznaniu naukowym występują, nieusuwalne, lecz zmienne, metafizyczne komponenty teorii naukowych. Komponenty te można dość dowolnie zmieniać, lecz nie da się ich całkowicie wyeliminować. ${ }^{61}$

Warunek Jodkowskiego jest już rozpoznawany i przybiera dwie formy: mocniejszą (istnieją podstawy, by wykluczyć wyjaśnienia naturalistyczne) oraz słabszą (istnieją podstawy, by dopuszczać wyjaśnienia nienaturalistyczne). Oto przykłady słabszej postaci warunku Jodkowskiego:

Ci, którzy przedstawiają empiryczne świadectwa na rzecz ID, nie muszą uzasadniać, że nie jest możliwe wyjaśnienie, które w ogóle nie odwołuje się do wyjaśnień celowych. Muszą oni jedynie uzasadnić, że, w świetle dostępnych danych, jest ono bardzo mało prawdopodobne. ${ }^{62}$

Odkrycie informacji zakodowanej w DNA oraz wielu układów o tzw. nieredukowalnej złożoności, np. złożony układ napędu wici bakterii [...], stawiają pod znakiem zapyta-

\footnotetext{
${ }^{60}$ Por. Jodkowski, „Uczony w ciemnym budynku...”, s. 57. Por. też Kazimierz JodKowski, „Kreacjonizm młodej Ziemi a koncepcja Big Bangu. Poglądy Johna Hartnetta z konstruktywistycznej i eksternalistycznej perspektywy”, Filozoficzne Aspekty Genezy 2015, t. 12, s. 74-76 [3779], http://www.nauka-a-religia.uz.zgora.pl/images/FAG/2015.t.12/art.12.pdf (14.02.2018); wypowiedź Kazimierza Jodkowskiego w: ByLICA, JoDKowski, Kilian i SAGAN, „Dyskusja nad artykułem Adama Groblera...”, s. 51; Kazimierz JoDKowski, „Racjonalność Kopernika i Darwina. Polemika z drem Eugeniuszem Moczydłowskim”, Na Poczatku... 2003, nr 11-12A (174-175), s. 435 [433448], www.nauka-a-religia.uz.zgora.pl/images/Przedruki/Jodkowski Racjonalnosc.Kopernika.i.D arwina.pdf (14.02.2018); Paul DE VRIES, „Naturalizm w naukach przyrodniczych. Perspektywa chrześcijańska”, przeł. Radosław Plato, Filozoficzne Aspekty Genezy 2011, t. 8, s. 123 [121-135], http://www.nauka-a-religia.uz.zgora.pl/images/FAG/2011.t.8/art.08.pdf (22.01.2018).

${ }^{61}$ Por. JodKowski, „Metafizyczne opowieści nauki...”, s. 80-81; JoDKowski, „Nienaukowy fundament nauki...”, s. 105; JodKowski, „Curriculum Vitae...”; Kazimierz Jodkowski, „Przedmowa”, Filozoficzne Aspekty Genezy 2004, t. 1, s. 5-6 [5-6], www.nauka-a-religia.uz.zgora.pl/images/FAG /2004.t.1/art.09.pdf (02.02.2018); Piotr ByLICA, „Kazimierza Jodkowskiego koncepcja epistemicznych układów odniesienia a teizm naturalistyczny Johna Polkinghorne’a”, w: ByLICA, KILIAN, PIOTROwSKI i SAGAN (red.), Filozofia - nauka - religia..., s. 192-193 [191-211], www.nauka-a-re ligia.uz.zgora.pl/images/Przedruki/Bylica Kazimierza.Jodkowskiego.koncepcja.epistemicznych.u kladow.odniesienia.pdf (18.01.2018); Mario A. LóPEZ, „Projekt jako kryterium demarkacji”, przeł. Dariusz Sagan, Filozoficzne Aspekty Genezy 2016, t. 13, s. 77 [75-100], www.nauka-a-religia.uz. zgora.pl/images/FAG/2016.t.13/art.12.pdf(12.02.2018).
}

${ }^{62}$ NAGEL, „Public Education and Intelligent Design...”, s. 199-200. 
nia naturalistyczne wyjaśnienia fenomenu życia. ${ }^{63}$

I przykłady mocniejszej postaci tego warunku:

Sukces programu Dembskiego, poświęconego poszukiwaniu wyspecyfikowanej złożoności w układach biologicznych, zależy od tego, czy jego „ogólny argument na rzecz eliminacji przypadku" [...] jest w stanie objąć - i wyeliminować - ewolucjonistyczne hipotezy wyjaśniające zajście jakiegoś zdarzenia. ${ }^{64}$

Materialiści mogą zaakceptować interwencję istot pozaziemskich, gdyby wykazano, że darwinowska teoria ewolucji nie jest w stanie wytłumaczyć jakiegoś przypadku złożoności biologicznej. ${ }^{65}$

Metodologiczny naturalizm wraz ze swoimi kontrwarunkami: nadnaturalistycznym i artyficjalistycznym nie są, oczywiście, jedynymi warunkami sine qua non naukowości. Tych ostatnich pojawiło się w nauce sporo. Są nimi, przykładowo, nakazy: poszukiwania ostatecznych uzasadnień i wyprowadzalności teorii z pierwszych przyczyn; wymogi: chronienia zjawisk i ich przewidywania; proliferacji i uporczywości; falsyfikowalności i konfirmowalności. ${ }^{66}$ Warunki te występowały wraz z określonymi przekonaniami metodologicznymi i pojawiały

\footnotetext{
${ }^{63}$ Adam Cenian, „Wiara w naukę - jej podstawy, założenia, mocne i słabe strony kultu”, wystąpienie na Konferencji Chrześcijańskiego Forum Pracowników Nauki: Nauka - Etyka Wiara, Rydzyna 30.05-02.06.2013, s. 153 [151-159], http://www.chfpn.pl/files/?id_plik=508 (12. 03.2018).

${ }^{64}$ Wesley R. ElsberRy, „«Tańczący z Popperem». Dembski o sprawdzalności”, przeł. Joanna Popek, Filozoficzne Aspekty Genezy 2011, t. 8, s. 187 [179-188], http://www.nauka-a-religia.uz. zgora.pl/images/FAG/2011.t.8/art.03.pdf (24.01.2018).

${ }^{65}$ Richard THornhill, „Historyczny związek między darwinizmem a argumentem z biologicznego projektu”, przeł. Anna Droś, Natalia Górska, Mateusz Krzyżanowski, Renata Merda, Zofia Sadowska i Dariusz Sagan, Filozoficzne Aspekty Genezy 2012, t. 9, s. 95 [79-105], http:// www.nauka-a-religia.uz.zgora.pl/images/FAG/2012.t.9/art.05.pdf (19.01.2018).

${ }^{66}$ Jak powszechnie wiadomo, falsyfikowalność i konfirmowalność były traktowane jako kryteria demarkacji. Jednakże, w świetle testu Laudana, okazały się co najwyżej warunkami koniecznymi. Por. w tej sprawie krytyczną uwagę Artura Koterskiego, „„Ostateczna» ocena demarkacjonizmu", w: Bylica, Kilian, PIotrowski i SAGAN (red.), Filozofia - nauka - religia..., s. 310 przyp. 7 [309-317]. Por. też Stephen C. Meyer, „The Use and Abuse of Philosophy of Science: A Response to Moreland", Perspectives on Science and Christian Faith 1994, vol. 46, no. 1, s. 19-21 [19-21], http://www.asa3.org/ASA/PSCF/1994/PSCF3-94Meyer.html (14.02.2018); Robert C. O'ConNOR, „Nauka przed sądem: analiza racjonalności naturalizmu metodologicznego”, przeł. Joanna Popek i Grzegorz Rogula, Filozoficzne Aspekty Genezy 2014, t. 11, s. 114-115 [95131], http://www.nauka-a-religia.uz.zgora.pl/images/FAG/2014.t.11/art.04.pdf (21.01.2018).
} 
się w następstwie przyjmowania określonych założeń filozoficznych dotyczących struktury i poznawalności świata. Warunki, o których tu mowa, narzucają poszukiwanie różnych, niezgodnych ze sobą twierdzeń faktualnych i prowadzą do odmiennych ocen metodologicznych.

Między naturalizmem i jego kontrwarunkami a warunkami wymienionymi w poprzednim akapicie zachodzi bardzo istotna różnica. Naturalizm i jego kontrwarunki wyrażają „największą możliwą” różnicę w poglądach naukowych, ${ }^{67}$ co oznacza, że najpierw przyjmowany jest określony EUO, a dopiero później inne warunki sine qua non naukowości. Dlatego te warunki naturalizmu i nienaturalizmu warto nazywać mocnymi warunkami sine qua non naukowości, celem odróżnienia ich od pozostałych, które można określać jako słabe warunki sine qua non naukowości. ${ }^{68}$

Istnieje co najmniej jeszcze jeden mocny warunek sine qua non naukowości — esencjalizm wyrażający się w takim języku, za pomocą którego możemy mówić o przedmiotach i ich abstrakcyjnych własnościach i dzięki któremu doświadczamy rzeczy $z$ ich istotowym rdzeniem. W kulturze zachodniej język ten kształtować się zaczął wraz z jońską filozofią przyrody i jej poszukiwaniami arché. Nowy język wypierać zaczął parataktyczny język homerycki. ${ }^{69}$ Ten ostatni

\footnotetext{
${ }^{67}$ JodKowski, „Kreacjoniści przed sądem...”, s. 177. Por. też BYLICA, „Kazimierza Jodkowskiego koncepcja...", s. 194-195.

${ }^{68}$ Por. Krzysztof J. Kilian, „Filozoficzne podstawy nauki”, Sofia. Pismo Filozofów Krajów Stowiańskich 2015, vol. 15, s. 79-81 [69-85], http://www.sofia.sfks.org.pl/05 Sofia Vol 15 Kil ian.pdf (04.02.2018); Krzysztof J. KiLIAN, „Filozofické podmienky sine qua non ve-deckosti”, w: Andrea Javorská, Lenka Kocinová i Simona Wagnerová (eds.), (META) FILOZOFIA — PRAX. Zborník vedeckých príspevkov, Bratislava 2016, s. 190-191 [186-193].

${ }^{69}$ Parataktyczny wszechświat nie jest spojony żadną podstawową substancją. Wszechświat ten składa się z elementów. Elementy tworzą agregaty parataktyczne. Element jest zawsze konkretem, na przykład rozpoznawalnym kształtem, zdarzeniem psychicznym, zdarzeniem fizycznym, sytuacją, obiektem (czyli agregatem percypowanych elementów o równym stopniu ważności), czynnością, wytworem czynności. Agregat parataktyczny (zespół równorzędnych części) jest kompleksem składającym się z określonych elementów o równym stopniu ważności (między elementami nie ma żadnej hierarchii). Jedyny związek, jaki zachodzi między elementami agregatu, to sekwencyjność (por. Kazimierz JodKowski i Krzysztof J. KiLIAN, „Feyerabendowskie rozwiązanie problemu psychofizycznego", w: Wiesław Dyк (red.), Sozologia systemowa. Tom V. Ekosfera. Czlowiek i jego środowisko w aspekcie przyrodniczym, filozoficznym i teologicznym, Uniwersytet Szczeciński. Rozprawy i studia, t. 877, Wydawnictwo Uniwersytetu Szczecińskiego, Szczecin 2013, s. 71-74 [61-76], www.nauka-a-religia.uz.zgora.pl/images/Przedruki/Jodkowski. Kilian_Feyerabendowskie.rozwiazanie.problemu.psychofizycznego.pdf (14.02.2018).
} 
nie pozwalał na mówienie o żadnej arché, idei czy formie.

Jeszcze Platon, ustami Sokratesa, wielokrotnie narzekał na niedostateczne ukorzenienie się nowego języka w jego czasach:

nie o to cię prosiłem, abyś mnie pouczył o jednym czy dwóch spośród wielu przypadków zbożności, ale o jej formie samej, przez którą wszystko, co zbożne, jest zbożne, [...] to dzięki jednej istocie rzeczy to, co bezbożne, jest bezbożne, a zbożne zostaje zbożnym. ${ }^{70}$

Z biegiem czasu jeden język - a co za tym idzie i określony sposób widzenia świata — zastąpiony został radykalnie innym, niewspółmiernym z nim językiem i radykalnie odmiennym, również niewspółmiernym z poprzednim, sposobem widzenia świata. ${ }^{71} \mathrm{~W}$ homeryckim świecie parataktycznym - co łatwo można zauważyć - nauka $\mathrm{w}$ znanej nam dziś postaci nie byłaby możliwa. Poszukiwania arché - zwłaszcza w postaci, jaką przypisywał jej Anaksymander — czegoś, co w żaden sposób nie da się uchwycić za pomocą zmysłów, doprowadziły nie tylko do przekonania, że u podłoża ujmowanych zmysłami zjawisk tkwi jakaś podstawowa substancja, pratworzywo wszystkiego, co jest. Poszukiwania arché, z biegiem czasu, doprowadziły do bardziej wyrafinowanego przekonania, w myśl którego istnieją przedmioty teoretyczne. O przedmiotach teoretycznych nie pozwalał mówić język mieszkańców świata parataktycznego. ${ }^{72}$

Esencjalizm, tak jak jest tutaj przedstawiony, ma jedną cechę wspólną z EUO. Komponenty te przyjmowane (lub zakładane) są przed innymi warunkami koniecznymi naukowości. Od EUO różni się tym, że jest wymogiem formalnym, mówi, jak formułować twierdzenia o rzeczywistości ${ }^{73}$ (choć pośrednio też

\footnotetext{
${ }^{70}$ Platon, Eutyfron, przeł. Władysław Witwicki, Państwowe Wydawnictwo Naukowe, Warszawa $1982,7 \mathrm{~d}$.

${ }^{71}$ Najogólniej rzecz biorąc, relacja niewspółmierności, jaka zachodzi miedzy językami, polega na tym, że języki takie tylko częściowo używają terminów o wspólnym znaczeniu, a zdania budowane za pomocą tego typu systemów znaczeniowych nie są w pełni na siebie przekładalne. Zaś niewspółmierne sposoby widzenia świata są efektem zmiany fundamentalnych przekonań dotyczących struktury świata i struktury każdego przedmiotu.

${ }^{72}$ Por. Kilian, „Filozofické podmienky sine qua non vedeckosti...”, s. 191.

${ }^{73}$ Jeśli wypowiadamy zdanie ,róża jest czerwona”, to sugerujemy, że istnieje substancja (róża) i przypadłość (czerwoność). Próba zakwestionowania tej sugestii, co robili na przykład reiści albo ewentyści, wymaga żmudnych zabiegów oraz perswazji i, de facto, nie jest traktowana jako poważna alternatywa dla esencjalizmu (por. JoDKowsKı i KILIAN, „Feyerabendowskie rozwią-
} 
informuje o tym, co jest samą rzeczywistością). Charakteryzowane EUO mówią, co jest dopuszczalnym przedmiotem badań, są zatem mocnymi materialnymi warunkami sine qua non naukowości.

\section{Nośniki EUO}

Filozofowie nauki, badając rozwój nauki, mówili — wymieniając tylko najważniejsze ujęcia - o: teoriach, paradygmatach i programach badawczych. EUO mogą być uznane za ich integralne składniki. Pojawiło się pytanie, czy warto oddzielać od nich EUO? ${ }^{74}$

Wydaje się, że można próbować umieszczać EUO w Popperowskich metafizycznych programach badawczych:

Nazwałem owe badawcze programy „metafizycznymi” dlatego, że wypływają z naszych ogólnych poglądów na strukturę świata, jak również z ogólnych poglądów na sytuację problemową panującą w kosmologii fizycznej. Nazwałem je „programami badawczymi”, ponieważ, łącznie z poglądem na to, czym są najdonioślejsze problemy, zawieraja one ogólna ideę, jak powinno wygladać zadowalające rozwiazanie owych problemów. ${ }^{75}$

Jednak te programy badawcze, które

mogą być określone mianem spekulatywnej fizyki lub, być może, jako spekulatywne antycypacje testowalnych teorii fizycznych $[\ldots]^{76}$

zanie problemu psychofizycznego...”, s. 65-66).

${ }^{74}$ Por. Kazimierz JoDKowsKi, „Konflikt nauka-religia a teoria inteligentnego projektu”, w: JoDKowsKI (red.), Teoria inteligentnego projektu..., s. 164 [145-180].

${ }^{75}$ Karl. R. Popper, Quantum Theory and the Schism in Physics: From the Postscript to the Logic of Scientific Discovery, ed. W.W. Bartley III, Rowman and Littlefield, Totowa, New Jersey 1982, s. 161 [wyróżnienia dodane].

${ }^{76}$ Popper, Quantum Theory..., s. 161-162. W swojej wcześniejszej wypowiedzi (1974) Popper zdawał się traktować metafizyczne programy badawcze szerzej, jako taką wszelką odmiane metafizyki, z której może wyewoluować falsyfikowalna teoria naukowa:

Doszedłem do wniosku, że darwinizm nie jest sprawdzalną teorią naukową, lecz metafizycznym programem badawczym [...]. Darwinizm jest metafizyką, ponieważ nie jest testowalny. 
są zbyt wąskim ujęciem dla EUO. Te ostatnie mają charakter bardziej uniwersalny, gdyż dotyczą wszystkich dyscyplin naukowych.

Zauważono, że EUO mogą być składnikami twardych rdzeni Lakatosowskich naukowych programów badawczych. Wtedy rdzenie takie składałyby się z dwóch rodzajów twierdzeń, które różniłyby się stopniem trwałości. Rdzeń mniej trwały to takie hipotezy, które pełnią rolę silnych heurystycznych zasad, rządzących rozwojem całego ciągu teorii, czyli to, co pod tym pojęciem rozumiał Lakatos. Bardziej trwały rdzeń to właśnie EUO:

w tym samym epistemicznym układzie odniesienia można formułować wiele alternatywnych teorii z wieloma różnymi twardymi rdzeniami. ${ }^{77}$

Przy takim ujęciu twierdzenia tworzące twardy rdzeń — zarówno jego mniej trwałe składniki, jak i jego bardziej trwałe elementy — miałyby jedną cechę wspólną: pełniłyby funkcję mocnych zasad heurystycznych. Różniłyby się nie tylko stopniem trwałości, ale i tym, o czym mówią. Te pierwsze to różnego rodzaju twierdzenia naukowe (na przykład trzy zasady newtonowskiej dynamiki), te drugie zaś to nietestowalne twierdzenia metafizyczne kierujące badaniami uczonych.

Racją za oddzielaniem twardych rdzeni od EUO jest to, że teorie z różnych dyscyplin naukowych, które mogą podzielać ten sam EUO, mogą różnić się swoimi twardymi rdzeniami. Może być i tak, że ten sam EUO podzielać mogą również alternatywne teorie w ramach danej dyscypliny:

Nawet teorie z różnych dyscyplin naukowych, jak fizyka, biologia, chemia czy astronomia, mogą zakładać i dzisiaj zakładają ten sam epistemiczny układ odniesienia (naturalizm metodologiczny). ${ }^{78}$

Karl R. Popper, Nieustanne poszukiwania. Autobiografia intelektualna, przeł. Adam Chmielewski, Wydawnictwo Znak, Kraków 1997, s. 235, 238.

${ }^{77}$ Jodкоwski, „Zasadnicza nierozstrzygalność...”, s. 220. Por. też wypowiedź Kazimierza Jodkowskiego w: Bylica, Jodkowski, Killan i SAgan, „Dyskusja nad artykułem Adama Groblera...", s. 53.

${ }^{78}$ JodKowski, „Nienaukowy fundament nauki...”, s. 103. Por. też JodKowski, „Epistemiczny układ odniesienia teorii inteligentnego projektu...”, s. 98-99; JodKоwski, „Zasadnicza nierozstrzygalność...", s. 220. 
Na pierwszy rzut oka Kuhnowskie macierze dyscyplinarne lepiej nadają się na nośniki EUO niż Lakatosowskie programy badawcze i nic nie stoi na przeszkodzie, by EUO umieścić jako składnik wartości, na przykład:

wszystkie teorie naukowe należy dopasowywać do odpowiednio rozumianej Księgi Rodzaju $^{79}$

lub modeli ontologicznych. ${ }^{80}$ Te ostatnie mówią o tym, co istnieje, na przykład:

przyroda jest domkniętym przyczynowo zbiorem materialnych bytów, w którym wszystkie zjawiska i procesy zachodzą zgodnie z określonymi prawami, stanowiącymi również element przyrody. ${ }^{8}$

Informują też o tym, w jaki sposób to, co istnieje, oddziałuje na siebie, na przykład:

wszystkie zjawiska i procesy przyrodnicze są rezultatem wyłącznie przyczyn naturalnych. ${ }^{82}$

\footnotetext{
${ }^{79}$ Por. Jodkowski, „Uczony w ciemnym budynku...”, s. 63-64.

${ }^{80}$ Por. Piotr ByLICA, „Główne założenia i problemy teizmu naturalistycznego w sprawie relacji sfery nadprzyrodzonej i świata przyrodniczego", w: Wiesław Dyк (red.), Sozologia systemowa. Tom IV. Biosfera. Czlowiek i jego środowisko w aspekcie przyrodniczym, filozoficznym i teologicznym, Uniwersytet Szczeciński. Rozprawy i studia, t. 824, Wydawnictwo Naukowe Uniwersytetu Szczecińskiego, Szczecin 2012, s. 67 [55-95], www.nauka-a-religia.uz.zgora.pl/images/ Przedruki/Bylica_Glowne.zalozenia.teizmu.naturalistycznego.pdf (21.01.2018).

${ }^{81}$ JodKowski, „Uczony w ciemnym budynku...”, s. 63; SAGAN, „Naturalizm metodologiczny — konieczny warunek naukowości...”, s. 74; BYLICA, „Główne założenia...”, s. 63; BYLICA and SAGan, „God, Design, and Naturalism...”, s. 623; Piotr BYlica, „Darwinizm i koncepcja wieloświata a religijne wyjaśnienie racjonalnego porządku i poznawalności przyrody", Zagadnienia Naukoznawstwa 2012, nr 3 (193) s. 196 [185-204], www.nauka-a-religia.uz.zgora.pl/images/Prze druki/Bylica_Darwinizm.i.koncepcja.wieloswiata.pdf (04.02.2018); BYLICA, Wspólczesny teizm naturalistyczny..., s. 38; Bruce L. GoRDON, „W obronie uniformitaryzmu”, przeł. Agnieszka Biesiadecka, Dorota Brylla, Małgorzata Gazda, Grzegorz Malec, Radosław Plato, Maciej Powąska, Alicja Ratajczak i Dariusz Sagan, Filozoficzne Aspekty Genezy 2014, t. 11, s. 137-138 [133-149], www.nauka-a-religia.uz.zgora.pl/images/FAG/2014.t.11/art.05.pdf (12.01.2018); Phillip E. JoHNson, „Co to jest darwinizm?”, przeł. Kazimierz Jodkowski, Na Początku... 2000, nr 7 (131-132), s. 197-211, http://apologetyka.com/ptkr/artykuly/PEJohnson3 (14.02.2018).

${ }^{82}$ Por. np. Jodkowski, „Nienaukowy fundament nauki...”, s. 100-103; Jodkowski, „Zasadnicza nierozstrzygalność...”, s. 216; Kazimierz JoDKowski, „Antynaturalizm teorii inteligentnego projektu”, Roczniki Filozoficzne 2006, t. 54, nr 2, s. 64 [63-76], www.nauka-a-religia.uz.zgora.pl/im ages/Przedruki/Jodkowski_Antynaturalizm.teorii.ID.pdf (09.02.2018); JoDKowski, „Dlaczego kre-
} 
W myśl ujęcia Kuhna wspólnoty uczonych funkcjonują na różnych poziomach. Przykładem najbardziej ogólnej wspólnoty jest społeczność wszystkich przyrodników. Na niższym poziomie funkcjonują wspólnoty fizyków, chemików, biologów i tym podobne. Jeszcze niższy poziom tworzą, przykładowo, chemicy organicy, fizycy kwantowi, biologowie ewolucyjni. ${ }^{83}$ Współczesna społeczność przyrodników w zasadzie podziela ten sam naturalistyczny EUO. Jeśli jednak składnikami macierzy są „,wszystkie lub większość [...] wspólnych grupie przekonań", ${ }^{84}$ to pojawia się pytanie, co należałoby uznać za takie wspólne całej społeczności przyrodników symboliczne generalizacje, modele heurystyczne, wartości czy wzorce? Efekt końcowy takiego uniwersalizującego przedsięwzięcia bardzo daleko odbiegałby od tego, co na co dzień przyjmują w swojej praktyce członkowie mniejszych wspólnot. ${ }^{85}$

Uznać należy, że ani twarde rdzenie, ani macierze dyscyplinarne nie nadają się na nośniki EUO i te ostatnie lepiej rozpatrywać w oddzieleniu od struktur, za

acjonizm jest pseudonauką...”, s. 322; Kazimierz JoDKowsKi, „Epistemiczne układy odniesienia i «warunek Jodkowskiego»", w: Anna Latawiec i Grzegorz BugaJaK (red.), Filozoficzne i naukowo-przyrodnicze elementy obrazu świata 7, Wydawnictwo Uniwersytetu Kardynała Stefana Wyszyńskiego, Warszawa 2008, s. 115 [108-123], http://tiny.pl/g28sn (11.02.2018); JoDKowski, „Kłopoty teistycznego ewolucjonizmu...”, s. 218; JoDKOwSKI, Spór ewolucjonizmu z kreacjonizmem..., s. 179-180; Zenon E. RoskaL, „Eksperyment MacDougalla w epistemicznym układzie odniesienia naturalizmu”, w: Bylica, KILIAN, PIotrowski i SAGAN (red.), Filozofia - nauka - religia..., s. 171 [165-172], www.nauka-a-religia.uz.zgora.pl/images/Przedruki/Roskal_Eksperyment. MacDougalla.pdf (02.07.2018); BYLICA, Wspólczesny teizm naturalistyczny..., s. 76; Michał Heller, Nowa fizyka i nowa teologia, Biblos, Tarnów 1992, s. 120; Heller, Sens życia i sens Wszechświata..., s. 45.

${ }^{83}$ Wbrew pozorom typowe wspólnoty nie sa zbyt liczne. Liczą około stu członków każda (a niekiedy znacznie mniej). Najbardziej wszechstronni uczeni należeć mogą (jednocześnie lub kolejno) do kilku takich społeczności (por. KunN, Struktura rewolucji naukowych..., s. 308; Thomas S. Kunn, „Raz jeszcze o paradygmatach”, w: Thomas S. Kunn, Dwa bieguny. Tradycja i nowatorstwo w badaniach naukowych, przeł. Stefan Amsterdamski, Państwowy Instytut Wydawniczy, Warszawa 1985, s. 410 [406-439]; Thomas S. KuHN, „Odpowiedź moim krytykom”, w: Thomas S. Kuнn, Droga po Strukturze. Eseje filozoficzne z lat 1970-1993 i wywiad-rzeka z autorem słynnej Struktury rewolucji naukowych, James Conant i John Haugeland (wyd.), przeł. Stefan Amsterdamski, Wydawnictwo Sic!, Warszawa 2003, s. 137-138 [117-162].

${ }^{84}$ Por. KuHn, Struktura rewolucji naukowych..., s. 315; KuHN, „Raz jeszcze o paradygmatach...", s. 439.

${ }^{85}$ Można jednak, na co wskazuje w swoim ujęciu Bylica, przedstawiać to jako elementy modeli poziomów analizy (w szczególności poziomu „metafizyki płytszej” — najogólniejszych, nietestowalnych twierdzeń o rzeczywistości empirycznej) (por. BYLICA, Współczesny teizm naturalistyczny..., s. 35-38, 212). 
pomocą których wyjaśniano rozwój nauki.

Za nośniki EUO uznać można interpretacje naturalne ${ }^{86}$ - konieczne i zmienne sposoby ujmowania badanych przedmiotów, ${ }^{87}$ głęboko zinternalizowane pojęcia, twierdzenia i schematy porządkowania rzeczywistości. Przykładowo:

Boga nie ma, albo jeśli istnieje, to [...] nie działa jako pierwszorzędna przyczyna; ${ }^{88}$

cokolwiek istnieje, może być zadowalająco wyjaśnione w terminologii przyrodniczej. ${ }^{89}$

Ich funkcjonowanie dostrzec można dopiero w konfrontacji „z radykalnie odmiennym sposobem myślenia". ${ }^{90}$

Na nośniki EUO nadają się również Lakatosowskie „podstawowe sądy wartościujące", ${ }^{91}$ czyli wartościowania dokonywane przez samych uczonych, oceniające konkretne osiągnięcia naukowe, na przykład:

powinniśmy odrzucić, dla zasady, hipotezę inteligentnego projektu jako substytut dialogu pomiędzy przypadkiem a koniecznością [...], ale musimy przyznać, że jak dotąd

\footnotetext{
${ }^{86}$ Por. JodKowsKI, „Twarde jądro ewolucjonizmu...”, s. 112.

${ }^{87}$ Por. np. JoDKowski, „Darwinowska teoria ewolucji jako teoria filozoficzna...”, s. 21; JoDKOWSKI, Spór ewolucjonizmu z kreacjonizmem..., s. 180.

Wyróżniono trzy podejścia do interpretacji naturalnych: (a) baconowskie - są one dodane do doświadczenia i dlatego można je wyeliminować po to, by ukazać we właściwej perspektywie badany przedmiot; (b) galileuszowe - są one koniecznymi, lecz zmiennymi, sposobami ujmowania badanych przedmiotów, nie da się ich wyeliminować z doświadczenia, należy umiejętnie zastępować jedne interpretacje naturalne drugimi; (c) kantowskie - są one koniecznymi i niezmiennymi składnikami doświadczenia (formami naoczności i kategoriami intelektu) (por. FEYERABEND, Przeciw metodzie..., s. 63-68).

${ }^{88}$ JodKowski, ,Twarde jądro ewolucjonizmu..., s. 112.

${ }^{89}$ William Henry WaLSH and Bruce Withington WILSHIRE, „Metaphysics”, w: Encyclopedia Britannica, https://www.britannica.com/topic/metaphysics/Types-of-metaphysical-theory\#toc 158 45 (15.01.2018), fragment w przekładzie Kazimierza JodKowsKIEGO, „Naturalizm ewolucjonizmu a wiara religijna. Przypadek Darwina", Przegląd Religioznawczy 1999, nr 1 (191), s. 17 [17-34], $\mathrm{http}: / /$ tiny.pl/q3m5c (15.01.2018).

${ }^{90}$ Por. JodkowsKi, „Twarde jądro ewolucjonizmu...”, s. 112.

${ }^{91}$ Por. Imre Lakatos, „Historia nauki a jej racjonalne rekonstrukcje”, w: LaKatos, Pisma z filozofii nauk empirycznych..., s. 222 [170-234].
} 
nie ma żadnych szczegółowych wyjaśnień darwinowskich dla ewolucji jakiegokolwiek systemu biochemicznego, a tylko różne pobożne spekulacje”. ${ }^{92}$

Sądy te, w połączeniu z podstawowymi ocenami naukowej elity, tworzą potoczną mądrość naukową. ${ }^{93}$

\section{Podsumowanie}

W niniejszym artykule wyjaśniono, dlaczego, omawiane do tej pory, EUO nigdy nie pełniły roli kryterium demarkacji. Jeśli weryfikacjoniści i falsyfikacjoniści mogą być zarówno nadnaturalistami, artyficjalistami, jak i naturalistami, to broniony przez nich nienaturalizm albo naturalizm nie jest częścią przyjmowanego przez nich kryterium demarkacji.

Argumentowano tam również, dlaczego EUO - mimo tego, że są jedynie warunkami koniecznymi naukowości - pełnią w nauce tak istotną rolę. Akceptacja jednego $\mathrm{z}$ nich jest równoznaczna $\mathrm{z}$ apriorycznym wykluczaniem warunków pozostałych i, co za tym idzie, $\mathrm{z}$ wykluczeniem innych możliwych sposobów wyjaśniania rzeczywistości.

Na przestrzeni dziejów sformułowano jednak sporo warunków koniecznych naukowości. Pojawia się zatem pytanie o to, czy EUO są w jakiś sposób warunkami wyróżnionymi. Aby odpowiedzieć na to pytanie, wprowadzono dwie dystynkcje: mocne i słabe oraz materialne i formalne warunki sine qua non.

${ }^{92}$ Franklin M. HARold, The Way of the Cell: Molecules, Organisms, and the Order of Life, Oxford University Press, Oxford 2001, s. 205 (cyt. za: BeHE, „Nieredukowalna złożoność...”, s. 74).

${ }^{93}$ Zdaniem węgierskiego filozofa każdy metodologiczny program badawczy oceniać należy na podstawie jego zgodności z danymi historycznymi (por. LAKaTos, „Historia nauki...”, s. 171179). Uwzględnianie danych historycznych polega na odwołaniu się do sumy „«podstawowych» ocen naukowej elity” (LaKatos, „Historia nauki...”, s. 213), czyli wzorców rozwoju nauki - reguł sugerujących określony sposób postępowania, na przykład „,ignoruj anomalie”, „dopuszczaj hipotezy ad hoc”, i „podstawowych sądów wartościujących” (LaKaTos, „Historia nauki...”, s. 222) - wartościowań oceniających konkretne osiągnięcia naukowe, na przykład „teoria względności Einsteina z 1919 roku jest lepsza od teorii Newtona w ujęciu Laplace'a”), które wspólnie tworzą „potoczną" - bo przyjętą przez większość uczonych — „mądrość naukową" (LAKatos, „Historia nauki...”, s. 209), a przez to właściwą podstawę dla dyskusji metodologicznych. W tej perspektywie najlepszy metodologiczny program badawczy (najlepsza racjonalna rekonstrukcja nauki) to ten, który jest w stanie wchłonąc najwięcej takich wartościowań (por. LAKATOS, „Historia nauki...”, s. 222-225). 
Odmienne EUO wyrażają najbardziej elementarną różnicę w poglądach na naukę. Oznacza to, że najpierw przyjmowany jest określony EUO, a dopiero później inne warunki sine qua non naukowości. Dlatego warunki naturalizmu i nienaturalizmu warto nazywać mocnymi warunkami sine qua non naukowości, celem odróżnienia ich od pozostałych, które można określać jako słabe warunki sine qua non naukowości. Należy przy tym zwrócić uwagę na to, że istnieje co najmniej jeszcze jeden mocny warunek sine qua non naukowości. Jest nim esencjalizm, wyrażający się w takim języku, za pomocą którego możemy mówić o przedmiotach i ich abstrakcyjnych własnościach. Tak rozumiany esencjalizm ma jedną cechę wspólną z EUO. Komponenty te są przyjmowane (lub zakładane milcząco) przed innymi warunkami koniecznymi naukowości. Od EUO różni się tym, że jest wymogiem formalnym - mówi, jak formułować twierdzenia o rzeczywistości. Charakteryzowane EUO mówią, co jest dopuszczalnym przedmiotem badań, są zatem mocnymi materialnymi warunkami sine qua non naukowości.

Podsumowując, powiedzieć należy, że EUO są zatem na tyle mocnymi warunkami, że wystarczają do wstępnego rozstrzygnięcia, czy danej propozycji teoretycznej przypisać można walor naukowości.

Kolejnym zagadnieniem, poruszanym w tym artykule, było kryterium odstępowania od wyjaśnień naturalistycznych i nienaturalistycznych. Dla wyjaśnień artyficjalistycznych sformułowano mocne - w przekonaniu niektórych filozofów - aprioryczne, kryterium, na mocy którego można odstąpić od wyjaśnień nienaturalistycznych. W myśl tego kryterium wystarczy podać kontrprzykład dla tezy: nie istnieje naturalna przyczyna, która jest w stanie wytworzyć nieredukowalną lub wyspecyfikowaną złożoność. Jak sygnalizowano, wadą tego kryterium jest to, że istnieje cała gama zabiegów immunizacyjnych, za pomocą których chronić można teorie przed „obaleniami”.

Dla wyjaśnień naturalistycznych takiego mocnego kryterium nie sformułowano. Niektórzy uznają to za wadę tego ujęcia. Starano się pokazać, że nie jest to wada, lecz zaleta. Wiadomo od dawna, że przestrzeganie apriorycznie nałożonych wymogów nie musi prowadzić do sukcesu poznawczego. Żądanie, by uczony jeszcze przed przystąpieniem do testowania teorii określił z góry warunki, w których zdecyduje się porzucić teorię, uznawane jest za nierealistyczne i bywa ignorowane. 
W artykule zastanawiano się również nad sensownością oddzielania EUO od programów badawczych i paradygmatów. Na pierwszy rzut oka EUO mogą być składnikami Popperowskich metafizycznych programów badawczych i twardych rdzeni Lakatosowskich programów badawczych, pełniąc w tych ostatnich rolę mocnych zasad heurystycznych, kierujących badaniami naukowymi. Można też próbować umieszczać je w Kuhnowskich macierzach dyscyplinarnych, gdzie mogą funkcjonować jako składnik wartości lub modeli ontologicznych.

Powodem oddzielania EUO od metafizycznych programów badawczych jest to, że te ostatnie sformułowane zostały wyłącznie dla fizyki, zaś EUO wyznaczają uniwersalną perspektywę uprawiania nauki.

Racją za oddzielaniem twardych rdzeni od EUO jest to, że teorie z różnych dyscyplin naukowych, które mogą podzielać ten sam EUO, mogą różnić się swoimi twardymi rdzeniami. Może być i tak, że ten sam EUO podzielać mogą również alternatywne teorie w ramach danej dyscypliny. De facto jest też tak, że teorie $\mathrm{z}$ różnych dyscyplin naukowych mogą zakładać i zakładają obecnie ten sam naturalistyczny EUO.

Zaś motywem oddzielania EUO od macierzy dyscyplinarnych jest to, że współczesna społeczność przyrodników w zasadzie podziela ten sam naturalistyczny EUO. Jeśli jednak składnikami macierzy są wszystkie lub większość wspólnych społeczności uczonych przekonań, to pojawia się pytanie, co należałoby uznać za wspólne całej społeczności przyrodników: symboliczne generalizacje, modele heurystyczne i wartości (inne niż te, które przyjmowane są dzięki akceptacji określonego EUO), czy wzorce? Efekt końcowy takiego uniwersalizującego przedsięwzięcia bardzo daleko odbiegałby od tego, co na co dzień przyjmują w swojej praktyce członkowie mniejszych społeczności.

Wskazano też, posiłkując się przykładami, że na nośniki EUO nadają się Feyerabendowskie interpretacje naturalne (nieusuwalne, lecz historycznie zmienne sposoby ujmowania badanych przedmiotów) i Lakatosowskie podstawowe sądy wartościujące (wartościowania dokonywane przez samych uczonych, oceniające konkretne osiągnięcia naukowe). 


\section{Bibliografia}

BEHE Michael J., Czarna skrzynka Darwina. Biochemiczne wyzwanie dla ewolucjonizmu, przeł. Dariusz Sagan, Biblioteka Filozoficznych Aspektów Genezy, t. 4, Wydawnictwo MEGAS, Warszawa 2008.

BEHE Michael J., „Filozoficzne zarzuty stawiane hipotezie inteligentnego projektu: odpowiedź na krytykę", przeł. Dariusz Sagan, Filozoficzne Aspekty Genezy 2004, t. 1, s. 115139, http://www.nauka-a-religia.uz.zgora.pl/images/FAG/2004.t.1/art.02.pdf (03.02.2018).

BeHE Michael J., „Nieredukowalna złożoność: problem dla ewolucjonizmu darwinowskiego", przeł. Dariusz Sagan, Filozoficzne Aspekty Genezy 2005/2006, t. 2/3, s. 67-96, http:// www.nauka-a-religia.uz.zgora.pl/images/FAG/2005-2006.t.2-3/art.01.pdf(12.01.2018).

Borczyk Bartosz, Chmielewski Adam, Elżanowski Andrzej, Jodkowski Kazimierz, LeszCZYŃSKi Damian, Lukierski Jerzy, Nysler Łukasz i PAwŁowski Bogusław, „Dyskusja”, w: LESZCZYŃSKi (red.), Ewolucja, filozofia, religia..., s. 155-172, www.nauka-a-religia.uz.zgo ra.pl/images/Przedruki/Jodkowski_Dyskusja.o.Darwinie.pdf(14.02.2018).

Boudry Maarten, Blancke Stefaan, and Braeckman Johan, „How Not to Attack Intelligent Design Creationism: Philosophical Misconceptions About Methodological Naturalism", Foundations of Science 2010, vol. 15, no. 3, s. 227-244, https://biblio.ugent.be/publication/ 956838/file/6828796.pdf (01.10.2017).

BRAND Leonard, „Naturalizm i jego rola w nauce”, przeł. Paulina Korzeniewska-Nowakowska, Filozoficzne Aspekty Genezy 2016, t. 13, s. 49-74, www.nauka-a-religia.uz.zgora.pl/im ages/FAG/2016.t.13/art.11.pdf (02.01.2018).

BugajaK Grzegorz, „Adekwatność tezy o rozdzielności płaszczyzn poznawczych. Głos w imieniu mieszkańców «opancerzonego bunkra»", w: Bylica, Kilian, Piotrowski i Sagan (red.), Filozofia — nauka — religia..., s. 173-190, www.nauka-a-religia.uz.zgora.pl/imag es/Przedruki/Bugajak_Adekwatnosc.tezy.o.rozdzielnosci.plaszczyzn.poznawczych.pdf (10. 02.2018).

BugajaK Grzegorz i TomczyK Jacek (red.), Kontrowersje wokól początków czlowieka, Księgarnia św. Jacka, Katowice 2007.

BYLICA Piotr, „Darwinizm i koncepcja wieloświata a religijne wyjaśnienie racjonalnego porządku i poznawalności przyrody", Zagadnienia Naukoznawstwa 2012, nr 3 (193) s. 185 204, www.nauka-a-religia.uz.zgora.pl/images/Przedruki/Bylica_Darwinizm.i.koncepcja.wi eloswiata.pdf (04.02.2018).

BYLICA Piotr, „Główne założenia i problemy teizmu naturalistycznego w sprawie relacji sfery nadprzyrodzonej i świata przyrodniczego", w: Dyk (red.), Sozologia systemowa. Tom 
IV..., s. 55-95, www.nauka-a-religia.uz.zgora.pl/images/Przedruki/Bylica_Glowne.zaloze nia.teizmu.naturalistycznego.pdf (21.01.2018).

ByLıca Piotr, „Kazimierza Jodkowskiego koncepcja epistemicznych układów odniesienia a teizm naturalistyczny Johna Polkinghorne'a", w: Bylica, Kilian, Piotrowski i Sagan (red.), Filozofia - nauka — religia..., s. 191-211, http://tiny.pl/g8h4z (18.01.2018).

ByLICA Piotr, „Konflikt między teizmem i nauką bazującą na naturalizmie — w ujęciu Phillipa E. Johnsona”, Zagadnienia Naukoznawstwa 2003, nr 3-4, s. 227-238, http://tiny.pl/ xh894 (02.01.2018).

ByLica Piotr, „Naturalizm metodologiczny jako warunek naukowości w kontekście relacji nauki i religii”, Przeglad Filozoficzny - Nowa Seria 2004, R. 13, nr 3 (51), s. 163-175, http://tiny.pl/xh8g4 (01.02.2018).

ByLıca Piotr, „Nauka światopoglądowo neutralna?”, Fronda 2012, nr 63, s. 67-80, http://ti ny.pl/gkfxr (28.12.2017).

Bylica Piotr, „Spór o naukowość teorii inteligentnego projektu”, w: Jodkowski (red.), Teoria inteligentnego projektu..., s. 51-78.

ByLICA Piotr, „Testowalność teorii inteligentnego projektu”, Filozofia Nauki 2003, R. XI, nr 2(42), s. 41-49, www.nauka-a-religia.uz.zgora.pl/images/Przedruki/Bylica_Testowalnosc. teorii.ID.pdf (04.02.2018).

BYLICA Piotr, Wspólczesny teizm naturalistyczny z punktu widzenia modelu poziomów analizy. Problem dzialania sfery nadnaturalnej w przyrodzie, Biblioteka Filozoficznych Aspektów Genezy, t. 7, Instytut Filozofii Uniwersytetu Zielonogórskiego, Zielona Góra 2016, www.nauka-a-religia.uz.zgora.pl/images/Przedruki/Bylica_Wspolczesny.teizm.natur alistyczny.pdf (16.01.2018).

Bylica Piotr, „Zaburzenia dysocjacyjne czy opętanie przez Szatana. Historyczno-metodologiczna analiza stosunku psychiatrii do problemu opętań”, w: Zon (red.), Pogranicza nauki..., s. 209-225, www.nauka-a-religia.uz.zgora.pl/images/Przedruki/Bylica_Zaburzenia. dysocjacyjne.pdf (01.02.2018).

Bylica Piotr, Jodkowski Kazimierz, Kilian Krzysztof J. i Sagan Dariusz, „Dyskusja nad artykułem Adama Groblera, «Słabości eksplanacyjne teorii inteligentnego projektu»”, Filozoficzne Aspekty Genezy 2013, t. 10, s. 17-63, www.nauka-a-religia.uz.zgora.pl/images/ FAG/2013.t.10/art.14.pdf (13.02.2018).

Bylica Piotr, Kilian Krzysztof J. i Sagan Dariusz, „Wstęp”, w: Bylica, Kilian, Piotrowski i SAGAN (red.), Filozofia - nauka - religia..., s. 11-33. 
Bylica Piotr, Kilian Krzysztof J., Piotrowski Robert i Sagan Dariusz (red.), Filozofia nauka - religia. Księga jubileuszowa dedykowana Profesorowi Kazimierzowi Jodkowskiemu z okazji 40-lecia pracy naukowej, Oficyna Wydawnicza Uniwersytetu Zielonogórskiego, Zielona Góra 2015, http://www.nauka-a-religia.uz.zgora.pl/images/Przedru ki/Filozofia.nauka.religia.pdf (17.03.2017).

Bylica Piotr and Sagan Dariusz, „God, Design, and Naturalism: Implications of Methodological Naturalism in Science for Science-Religion Relation", Pensamiento 2008, vol. 64, núm. 242, s. 621-638, http://www.nauka-a-religia.uz.zgora.pl/images/Przedruki/Bylica.Sag an_God.Design.and.Naturalism.pdf (31.01.2018).

Cenian Adam, „Wiara w naukę — jej podstawy, założenia, mocne i słabe strony kultu”, wystąpienie na Konferencji Chrześcijańskiego Forum Pracowników Nauki: Nauka - Etyka - Wiara, Rydzyna 30.05-02.06.2013, s. 151-159, http://www.chfpn.pl/files/?id_plik=508 (12.03.2018).

Chaberek Michał OP, „Neodarwinizm skończy jak marksizm. Rozmowa z Jay’em W. Richardsem", Fronda 2012, nr 63, s. 43-47.

Coyne Jerry A., „Nowa fala fanatyzmu w nauce”, przeł. Dariusz Sagan, Filozoficzne Aspekty Genezy 2004, t. 1, s. 49-53, http://www.nauka-a-religia.uz.zgora.pl/images/FAG/2004. t.1/art.01.pdf (02.02.2018).

CRombie Alistair Cameron (ed.), Scientific Change: Historical Studies in the Intellectual, Social and Technical Conditions for Scientific Discovery and Technical Invention, from Antiquity to the Present, Symposium on the History of Science, University of Oxford 9-15 July 1961, Heinemann, London 1963.

DAwKINS Richard, Ślepy zegarmistrz, czyli jak ewolucja dowodzi, że świat nie zostal zaplanowany, przel. Antoni Hoffman, Biblioteka Myśli Wspótczesnej, Państwowy Instytut Wydawniczy, Warszawa 1994.

DE Duve Christian, „The Beginning of Life on Earth”, American Scientist 1995, vol. 83, s. 428-437, http://pratclif.com/memes/deduve-begin-life1.html (07.02.2018).

Delfino Robert A., „Naturalizm metodologiczny i ewolucja”, przeł. Rafał Lizut, w: JAROsZYŃSKI (red.), Ewolucjonizm czy kreacjonizm..., s. 137-156.

Delfino Robert A., „Replacing Methodological Naturalism”, Metanexus 24 May 2007, http: //www.metanexus.net/essay/replacing-methodological-naturalism (05.02.2018).

Dembsк William A., Intelligent Design: The Bridge between Science and Theology, InterVarsity Press, Downers Grove, Illinois 1999. 
Dembsкi William A., „Odmiany naturalizmu. Czy któraś forma naturalizmu jest zgodna z teorią inteligentnego projektu?", przeł. Dariusz Sagan, Na Poczatku... 2005, R. 13, nr 12, s. 45-54, http://tiny.pl/xhkg8 (05.02.2018).

Dемвsк William A., The Design Revolution: Answering the Toughest Questions about Intelligent Design, InterVarsity Press, Downers Grove, Illinois 2004.

DE VRIES Paul, „Naturalizm w naukach przyrodniczych. Perspektywa chrześcijańska”, przeł. Radosław Plato, Filozoficzne Aspekty Genezy 2011, t. 8, s. 121-135, http://www.nauka-a-re ligia.uz.zgora.pl/images/FAG/2011.t.8/art.08.pdf (22.01.2018).

Dębowski Józef i Starzý́ska-Kościuszko Ewa (red.), Nauka. Racjonalność. Realizm. Między filozofią przyrody a filozofią nauki i socjologią wiedzy, Instytut Filozofii Uniwersytetu Warmińsko-Mazurskiego w Olsztynie, Olsztyn 2013.

Discovery Institute, „Falsyfikowalność teorii inteligentnego projektu”, przeł. Dariusz Sagan, Na Początku ... 2005, nr 11-12A (200-201), s. 455-457, www.nauka-a-religia.uz.zgora. pl/images/Przedruki/Discovery.Institute_Falsyfikowalnosc.teorii.ID.pdf(12.02.2018).

Dүк Wiesław (red.), Sozologia systemowa. Tom IV. Biosfera. Czlowiek i jego środowisko w aspekcie przyrodniczym, filozoficznym i teologicznym, Uniwersytet Szczeciński. Rozprawy i studia, t. 824, Wydawnictwo Naukowe Uniwersytetu Szczecińskiego, Szczecin 2012.

Dүк Wiesław (red.), Sozologia systemowa. Tom V. Ekosfera. Czlowiek i jego środowisko w aspekcie przyrodniczym, filozoficznym i teologicznym, Uniwersytet Szczecinski. Rozprawy i studia, t. 877, Wydawnictwo Uniwersytetu Szczecińskiego, Szczecin 2013.

EDIS Taner, „Dlaczego «teoria inteligentnego projektu» jest bardziej interesująca niż tradycyjny kreacjonizm”, przeł. Dariusz Sagan, Filozoficzne Aspekty Genezy 2007/2008, t. 6/7, s. 81-93, www.nauka-a-religia.uz.zgora.pl/images/FAG/2007-2008.t.4-5/art.08.pdf (04.02. 2018).

EldRedge Niles, The Monkey Business: A Scientist Looks at Creationism, Washington Square Press, New York 1982.

ElDREDge Niles, The Triumph of Evolution and the Failure of Creationism, W.H. Freeman and Company, New York 2001.

ElSBERry Wesley R., „«Tańczący z Popperem». Dembski o sprawdzalności”, przeł. Joanna Popek, Filozoficzne Aspekty Genezy 2011, t. 8, s. 179-188, http://www.nauka-a-religia.uz. zgora.pl/images/FAG/2011.t.8/art.03.pdf (24.01.2018).

Feyerabend Paul K., „Against Method: Outline of an Anarchistic Theory of Knowledge”, w: RADNER and WinOKUR (eds.), Analyses of Theories and Methods..., s. 17-130. 
FEYERABEND Paul K., Jak być dobrym empirystą, przeł. Krystyna Zamiara, PWN, Warszawa 1979.

Feyerabend Paul K., „Ku pocieszeniu specjalisty”, w: Feyerabend, Jak być dobrym empirystą..., s. 200-250.

Feyerabend Paul K., Przeciw metodzie, przeł. Stefan Wiertlewski, Wydawnictwo Siedmioróg, Wrocław 1996.

FEYERABEND Paul K., „,Realizm i instrumentalizm. Uwagi o logice potwierdzania przez fakty", w: FEYERABEND, Jak być dobrym empirystą..., s. 152-193.

Feyerabend Paul K., Zabijanie czasu, przeł. Tomasz Bieroń, Wydawnictwo Znak, Kraków 1996.

Frank Phillip G., The Validation of Scientific Theories, The Beacon Press, Boston 1956.

Frank Phillip G., „The Variety of Reasons for the Acceptance of Scientific Theories”, w: FRANK, The Validation of Scientific Theories..., s. 3-28.

GAzDA Małgorzata, „Stephena C. Meyera argument na rzecz projektu w przyrodzie a warunek Jodkowskiego", Filozoficzne Aspekty Genezy 2015, t. 12, s. 287-301, http://www.nau ka-a-religia.uz.zgora.pl/images/FAG/2015.t.12/art.13.pdf (14.02.2018).

Gordon Bruce L., „W obronie uniformitaryzmu”, przeł. Agnieszka Biesiadecka, Dorota Brylla, Małgorzata Gazda, Grzegorz Malec, Radosław Plato, Maciej Powąska, Alicja Ratajczak i Dariusz Sagan, Filozoficzne Aspekty Genezy 2014, t. 11, s. 133-149, http://www.na uka-a-religia.uz.zgora.pl/images/FAG/2014.t.11/art.05.pdf (12.01.2018).

Harold Franklin M., The Way of the Cell: Molecules, Organisms, and the Order of Life, Oxford University Press, Oxford 2001.

Heller Michał, Nowa fizyka i nowa teologia, Biblos, Tarnów 1992.

Heller Michał, Sens życia i sens Wszechświata. Studia z teologii współczesnej, Biblos, Tarnów 2002.

Hoffman Antoni, „Wstęp”, w: Dawkins, Ślepy zegarmistrz..., s. 5-10.

JANECZeK Stanisław, Starościc Anna, DĄBEK Dariusz i Herda Justyna (red.), Filozofia przyrody, Dydaktyka Filozofii, t. III, Wydawnictwo Katolickiego Uniwersytetu Lubelskiego, Lublin 2013.

J ARoszyński Piotr (red.), Ewolucjonizm czy kreacjonizm, Przyszłość Cywilizacji Zachodu, Fundacja „Lubelska Szkoła Filozofii Chrześcijańskiej”, Lublin 2008.

Javorská Andrea, Kocinová Lenka i Wagnerová Simona (eds.), (META) FILOZOFIA PRAX. Zborník vedeckých príspevkov, Bratislava 2016. 
JoDкошsкı Kazimierz, „Antynaturalizm teorii inteligentnego projektu”, Roczniki Filozoficzne 2006, t. 54, nr 2, s. 63-76, www.nauka-a-religia.uz.zgora.pl/images/Przedruki/Jodkow ski_Antynaturalizm.teorii.ID.pdf (09.02.2018).

JoDKowsкı Kazimierz, „Curriculum Vitae”, http://tiny.pl/gkfxf (03.02.2018).

JoDKошsкi Kazimierz, „Darwinowska teoria ewolucji jako teoria filozoficzna” w: KonSTAŃCZAK i TUROWSKI (red.), Filozofia jako mądrość bycia..., s. 17-23, http://tiny.pl/q3m56 (11.02.2018).

JoDKошsкı Kazimierz, „Dlaczego kreacjonizm jest pseudonauką?”, w: Zon (red.), Pogranicza nauki..., s. 317-323, www.nauka-a-religia.uz.zgora.pl/images/Przedruki/Jodkowski_ Dlaczego.kreacjonizm.jest.pseudonauka.pdf (31.01.2018).

JoDKоwsкi Kazimierz, „Epistemiczne układy odniesienia i «warunek Jodkowskiego»”, w: LATAWIEC i BUGAJAK (red.), Filozoficzne i naukowo-przyrodnicze elementy..., s. 108-123, http://tiny.pl/g28sn (11.02.2018).

JoDкошsкі Kazimierz, „Epistemiczny układ odniesienia teorii inteligentnego projektu”, Filozofia Nauki 2006, nr 1 (53), s. 95-105, www.nauka-a-religia.uz.zgora.pl/images/Inne.tek sty/Jodkowski_Epistemiczny.uklad.odniesienia.teorii.ID.pdf (98.02.2018).

JoDкоwsкi Kazimierz, „Eskapizm teologii i filozofii katolickiej w sprawie «nauka a religia»", Na Poczatku ... 2005, nr 7-8 (196-197), s. 261-284, www.nauka-a-religia.uz.zgora. pl/images/Przedruki/Jodkowski_Eskapizm.teologii.i.filozofii.katolickiej.pdf (18.02.2018).

JoDkowsкi Kazimierz, „Falsyfikacjonizm a wzrost wiedzy”, Annales UMCS 1977, Sec. I, Philosophia-Sociologia, vol. 2, s. 255-272.

JodKowski Kazimierz, „Kłopoty teistycznego ewolucjonizmu”, w: BugAJAK i ToмczYK (red.), Kontrowersje wokól początków czlowieka..., s. 209-224, http://tiny.pl/xhkgl (31. 01.2018).

JoDкоwsкı Kazimierz, „Konflikt nauka-religia a teoria inteligentnego projektu”, w: JoDKоWSKI (red.), Teoria inteligentnego projektu..., s. 145-180.

JoDKоwsкi Kazimierz, „Kreacjoniści przed sądem. Aspekty filozoficzne «małpich procesów»", w: Michalczenia, Mizí́ska i Ossowska (red.), Poszukiwania filozoficzne. Tom I..., s. 175-198, www.nauka-a-religia.uz.zgora.pl/images/Przedruki/Jodkowski_Kreacjoni sci.przed.sadem.Aspekty.filozoficzne.malpich.procesow.pdf (02.01.2018).

JoDKошsкı Kazimierz, „Kreacjonizm młodej Ziemi a koncepcja Big Bangu. Poglądy Johna Hartnetta z konstruktywistycznej i eksternalistycznej perspektywy", Filozoficzne Aspekty Genezy 2015, t. 12, s. 37-79, http://www.nauka-a-religia.uz.zgora.pl/images/FAG/2015.t.12 /art.12.pdf (14.02.2018). 
JoDKowski Kazimierz, „Metafizyczne opowieści nauki jako fundament pluralizmu naukowego", w: Johnson, Wielka metafizyczna opowieść nauki..., s. 74-85, http://tiny.pl/q3 m5p (13.01.2018).

JоDкошSкі Kazimierz, Metodologiczne aspekty kontrowersji ewolucjonizm-kreacjonizm, Realizm. Racjonalność. Relatywizm, t. 35, Wydawnictwo UMCS, Lublin 1998.

JoDKоwsкı Kazimierz, „Naturalizm ewolucjonizmu a wiara religijna. Przypadek Darwina”, Przeglad Religioznawczy 1999, nr 1 (191), s. 17-34, http://tiny.pl/q3m5c (15.01.2018).

JodKowsкi Kazimierz, „Nienaukowy fundament nauki”, w: PIETRZAK (red.), Granice nauki..., s. 59-108, www.nauka-a-religia.uz.zgora.pl/images/Przedruki/Jodkowski_Nienauko wy.fundament.nauki.pdf (12.02.2018).

JoDкоwsкi Kazimierz, „Przedmowa”, Filozoficzne Aspekty Genezy 2004, t. 1, s. 5-6, www. nauka-a-religia.uz.zgora.pl/images/FAG/2004.t.1/art.09.pdf (02.02.2018).

Jоркошsкı Kazimierz, „Racjonalność Kopernika i Darwina. Polemika z drem Eugeniuszem Moczydłowskim", Na Poczatku... 2003, nr 11-12A (174-175), s. 433-448, www.nauka-a-re ligia.uz.zgora.pl/images/Przedruki/Jodkowski_Racjonalnosc.Kopernika.i.Darwina.pdf (14. 02.2018).

JoDкошsкі Kazimierz, „Rozpoznawanie genezy: istota sporu ewolucjonizm-kreacjonizm”, Roczniki Filozoficzne 2002, t. 50, z. 3, s. 187-198, www.nauka-a-religia.uz.zgora.pl/images/ Przedruki/Jodkowski_Rozpoznawanie.genezy.pdf (12.02.2018).

JoDKошsкi Kazimierz, „Ruch kreacjonistyczny jest elementem pluralizmu naukowego”, Przeglad Filozoficzny - Nowa Seria 2001, R. X, nr 1 (37), s. 241-253, http://tiny.pl/gdw95 (02.02.2018).

JoDKошsкı Kazimierz, Spór ewolucjonizmu z kreacjonizmem. Podstawowe pojęcia i poglądy, Biblioteka Filozoficznych Aspektów Genezy, t. 1, Wydawnictwo MEGAS, Warszawa 2007, www.nauka-a-religia.uz.zgora.pl/images/Przedruki/Jodkowski_Spor.ewolucjonizmu. z.kreacjonizmem.pdf (19.01.2018).

JoDкоwsкi Kazimierz (red.), Teoria inteligentnego projektu — nowe rozumienie naukowości?, Biblioteka Filozoficznych Aspektów Genezy, t. 2, Wydawnictwo MEGAS, Warszawa 2007, http://www.nauka-a-religia.uz.zgora.pl/images/Przedruki/Jodkowski_red._Teoria. ID.nowe.rozumienie.naukowosci.pdf (20.01.2018).

JoDKowski Kazimierz, „Twarde jądro ewolucjonizmu”, Roczniki Filozoficzne 2003, t. 51, z. 3, s. 77-117, www.nauka-a-religia.uz.zgora.pl/images/Przedruki/Jodkowski_Twarde.jadr o.ewolucjonizmu.pdf (12.02.2018). 
JoDKowskı Kazimierz, „Uczony w ciemnym budynku. Na marginesie metafory Elżbiety Kaluszyńskiej”, w: Dębowski i StarzyńsKa-Kościuszko (red.), Nauka. Racjonalność. Realizm..., s. 55-67, www.nauka-a-religia.uz.zgora.pl/images/Przedruki/Jodkowski_Uczony. w.ciemnym.budynku.pdf (14.01.2018).

JоDкошsк Kazimierz, „W poszukiwaniu twardego jądra ewolucjonizmu”, Filozofia Nauki 2001, nr 2 (34), s. 7-18, www.nauka-a-religia.uz.zgora.pl/images/Przedruki/Jodkowski_W. poszukiwaniu.twardego.jadra.ewolucjonizmu.pdf (15.02.2018).

JoDКоWSкI Kazimierz, Wspólnoty uczonych, paradygmaty i rewolucje naukowe, Realizm. Racjonalność. Relatywizm, t. 22, Wydawnictwo UMCS, Lublin 1990.

JoDKowsкi Kazimierz, „Zasadnicza nierozstrzygalność sporu ewolucjonizm-kreacjonizm”, Przeglad Filozoficzny - Nowa Seria 2012, nr 3 (83), s. 201-222, http:/tiny.pl/gkfxn (18. 02.2018).

JodKowski Kazimierz i Kitıan Krzysztof J., „Feyerabendowskie rozwiązanie problemu psychofizycznego", w: Dүк (red.), Sozologia systemowa. Tom V..., s. 61-76, http://tiny.pl/gq kds (14.02.2018).

Johnson Phillip E., „Co to jest darwinizm?”, przeł. Kazimierz Jodkowski, Na Poczatku... 2000, nr 7 (131-132), s. 197-211, http://apologetyka.com/ptkr/artykuly/PEJohnson3 (14.02. 2018).

Johnson Phillip E., Wielka metafizyczna opowieśé nauki (z poslowiem Kazimierza Jodkowskiego), przeł. Piotr Bylica, Archiwum Na Poczq̨tku..., z. 13, Polskie Towarzystwo Kreacjonistyczne, Warszawa 2003.

KenYon Dean H., „Kreacjonistyczne ujęcie pochodzenia życia”, przeł. Kazimierz Jodkowski, w: JodKowsкi, Metodologiczne aspekty..., s. 482-495.

KILIAN Krzysztof J., „Filozofické podmienky sine qua non vedeckosti”, w: JAVORSKÁ, Kocinová i Wagnerová (eds.), (META) FILOZOFIA — PRAX..., s. 186-193.

Kilian Krzysztof J., „Filozoficzne podstawy nauki”, Sofia. Pismo Filozofów Krajów Stowiańskich 2015, vol. 15, s. 69-85, http://www.sofia.sfks.org.pl/05_Sofia_Vol_15_Kilian. pdf (04.02.2018).

Kilıan Krzysztof. J., „Geneza idei epistemicznych układów odniesienia i ich odmiany”, Filozoficzne Aspekty Genezy 2017, t. 14, s. 137-190, http://www.nauka-a-religia.uz.zgora.pl/ images/FAG/2017.t.14/art.05.pdf (08.04.2018).

Kitian Krzysztof J., Poglądy filozoficzne Paula K. Feyerabenda. Czę̧ś I. Program metodologiczny, Oficyna Wydawnicza Uniwersytetu Zielonogórskiego, Zielona Góra 2014. 
KoJonen Erkki V.R., „Methodological Naturalism and the Truth Seeking Objection”, International Journal for Philosophy of Religion 2016, vol. 79, no. 3, s. 1-26, http://tiny.pl/gkf xk (12.02.2018).

Konstańczak Stefan i Turowski Tomasz (red.), Filozofia jako mądrość bycia. Profesorowi Krzysztofowi Kaszyńskiemu w darze z okazji 70. urodzin, Oficyna Wydawnicza Uniwersytetu Zielonogórskiego, Zielona Góra 2009.

KоTERSкI Artur, Falsyfikacjonistyczne kryteria demarkacji w XX-wiecznej filozofii nauki, Wydawnictwo UMCS, Lublin 2004.

Koterski Artur, „«Ostateczna» ocena demarkacjonizmu”, w: BylicA, Kilian, Piotrowski i SAGAN (red.), Filozofia — nauka - religia..., s. 309-317.

KотеRSкI Artur, Weryfikacjonistyczne kryteria demarkacji w filozofii nauki Koła Wiedeńskiego, Centrum Nauki Języka Angielskiego Metodą Allana, Akces, Poznań 2002.

KuнN Thomas S., Droga po Strukturze. Eseje filozoficzne z lat 1970-1993 i wywiad-rzeka z autorem slynnej Struktury rewolucji naukowych, James Conant i John Haugeland (wyd.), przeł. Stefan Amsterdamski, Wydawnictwo Sic!, Warszawa 2003.

KuHn Thomas S., Dwa bieguny. Tradycja i nowatorstwo w badaniach naukowych, przeł. Stefan Amsterdamski, Państwowy Instytut Wydawniczy, Warszawa 1985.

Kunn Thomas S., „Odpowiedź moim krytykom”, w: KunN, Droga po Strukturze..., s. $117-162$.

Kuнn Thomas S., „Raz jeszcze o paradygmatach”, w: Kunn, Dwa bieguny..., s. 406-439.

KuHn Thomas S., Struktura rewolucji naukowych, przeł. Helena Ostromęcka i Justyna Nowotniak, Aletheia, Warszawa 2001.

KuHn Thomas S., „The Function of Dogma in Scientific Research”, w: CRombiE (ed.), Scientific Change..., s. 347-369.

LAKATOS Imre, „Falsyfikacja a metodologia naukowych programów badawczych”, w: LAKATOS, Pisma z filozofii nauk empirycznych..., s. 3-169.

LAKatos Imre, „Historia nauki a jej racjonalne rekonstrukcje”, w: LAKATos, Pisma z filozofii nauk empirycznych..., s. 170-234.

LaKatos Imre, Pisma z filozofii nauk empirycznych, przeł. Wojciech Sady, Biblioteka Wspótczesnych Filozofów, Wydawnictwo Naukowe PWN, Warszawa 1995.

Latawiec Anna i BugajaK Grzegorz (red.), Filozoficzne i naukowo-przyrodnicze elementy obrazu świata 7, Wydawnictwo Uniwersytetu Kardynała Stefana Wyszyńskiego, Warszawa 2008 . 
Leszczyński Damian (red.), Ewolucja, filozofia, religia, Lectiones \& Acroases Philosophicae 2010, vol. III.

López Mario A., „Projekt jako kryterium demarkacji”, przeł. Dariusz Sagan, Filozoficzne Aspekty Genezy 2016, t. 13, s. 75-100, www.nauka-a-religia.uz.zgora.pl/images/FAG/2016. t.13/art.12.pdf (12.02.2018).

MeYer Stephen C., „DNA a pochodzenie życia. Informacja, specyfikacja i wyjaśnienie”, przeł. Dariusz Sagan, Filozoficzne Aspekty Genezy 2005/2006, t. 2/3, s. 133-215, http:// www.nauka-a-religia.uz.zgora.pl/images/FAG/2005-2006.t.2-3/art.12.pdf (31.01.2018).

Meyer Stephen C., „The Use and Abuse of Philosophy of Science: A Response to Moreland", Perspectives on Science and Christian Faith 1994, vol. 46, no. 1, s. 19-21, http:// www.asa3.org/ASA/PSCF/1994/PSCF3-94Meyer.html (14.02.2018).

Michalczenia Jakub, Mizí́sKa Jadwiga i Ossowska Katarzyna (red.), Poszukiwania filozoficzne. Tom I: Nauka, Prawda. Panu Profesorowi Józefowi Dębowskiemu w darze, Instytut Filozofii Uniwersytetu Warmińsko-Mazurskiego w Olsztynie, Olsztyn 2014.

NAGel Thomas, „Public Education and Intelligent Design”, Philosophy \& Public Affairs 2008, vol. 36, no. 2, s. 187-205.

O’ConNoR Robert C., „Nauka przed sądem: analiza racjonalności naturalizmu metodologicznego", przeł. Joanna Popek i Grzegorz Rogula, Filozoficzne Aspekty Genezy 2014, t. 11, s. 95-131, http://www.nauka-a-religia.uz.zgora.pl/images/FAG/2014.t.11/art.04.pdf (21.01.2018).

Parascandalo Renato and Hösle Vittorio, „Three Interviews with Paul K. Feyerabend”, Teleos: A Quarterly Journal of Critical Thought 1995, no. 102, s. 115-148.

PenNock Robert T., „Bóg w lukach wiedzy: argument z niewiedzy i ograniczenia naturalizmu metodologicznego", przeł. Dariusz Sagan, Filozoficzne Aspekty Genezy 2012, t. 9, s. 155-185, http://www.nauka-a-religia.uz.zgora.pl/images/FAG/2012.t.9/art.04.pdf (03.02. 2018).

Pennock Robert T., „Creationism and Intelligent Design”, Annual Review of Genomics and Human Genetics 2003, vol. 4, s. 143-163, http://bio.classes.ucsc.edu/bio175/Other/Pennock _2003.pdf (19.01.2018).

PerAKH Mark, „Nieredukowalna sprzeczność”, przeł. Dariusz Sagan, Filozoficzne Aspekty Genezy 2004, t. 1, s. 71-113, www.nauka-a-religia.uz.zgora.pl/images/FAG/2004.t.1/art.04. pdf (28.01.2018). 
PетRICH Loren, „Artefakty zwierzęce i pozaziemskie - inteligentnie zaprojektowane?”, przeł. Dariusz Sagan, Filozoficzne Aspekty Genezy 2009/2010, t. 6/7, s. 139-153, http:// www.nauka-a-religia.uz.zgora.pl/images/FAG/2009-2010.t.6-7/art.06.pdf (25.01.2018).

Pietrzak Zbigniew (red.), Granice nauki, Lectiones \& Acroases Philosophicae 2013, vol. VI, nr 1 .

Pigluucci Massimo, Tales of the Rational: Skeptical Essays About Nature and Science, Freethought Press, Atlanta, Georgia 2000.

PIотRошккI Robert, „Kazimierz Jodkowski, Spór ewolucjonizmu z kreacjonizmem. Podstawowe pojęcia i poglądy, Megas, Warszawa 2007 (Biblioteka Filozoficznych Aspektów Genezy, t. 1), ss. 260", Spoleczeństwo. Studia. Prace badawcze. Dokumenty z zakresu spotecznej nauki Kościoła 2010, R. XX (XVI), nr 1, s. 169-172, http://tiny.pl/g8hnq (15.02. 2018).

Platon, Eutyfron, przeł. Władysław Witwicki, Państwowe Wydawnictwo Naukowe, Warszawa 1982

Polany Michael, „The Republic of Science: Its Political and Economic Theory”, Minerva 2000, vol. 38, s. 1-32 (przedruk z: „Minerva” 1962, vol. 1, s. 54-73).

PopPER Karl R., Logika odkrycia naukowego, przeł. Urszula Niklas, Państwowe Wydawnictwa Naukowe, Warszawa 1979.

PopPer Karl R., Nieustanne poszukiwania. Autobiografia intelektualna, przeł. Adam Chmielewski, Wydawnictwo Znak, Kraków 1997.

Popper Karl. R., Quantum Theory and the Schism in Physics: From the Postscript to the Logic of Scientific Discovery, ed. W.W. Bartley III, Rowman and Littlefield, Totowa, New Jersey 1982.

Popper Karl R., „Wiedza hipotetyczna. Moje rozwiązanie problemu indukcji”, w: PopPer, Wiedza obiektywna..., s. 9-49.

PoPPER Karl R., Wiedza obiektywna. Ewolucyjna teoria epistemologiczna, przeł. Adam Chmielewski, Wydawnictwo Naukowe PWN, Warszawa 1992.

Provine William B., „Projekt? Tak! Ale czy inteligentny?”, przeł. Sławomir Piechaczek, Filozoficzne Aspekty Genezy 2005/2006, t. 2/3, s. 223-224, http://www.nauka-a-religia.uz. zgora.pl/images/FAG/2005-2006.t.2-3/art.10.pdf(12.03.2018).

RADNER Michael and WinoKur Stephen (eds.), Analyses of Theories and Methods of Physics and Psychology, Minnesota Studies in the Philosophy of Science 1970.

Ratzsch Del, Science \& Its Limits: The Natural Sciences in Christian Perspective, InterVarsity Press, Downers Grove, Illinois 2000. 
Roskal Zenon E., „Eksperyment MacDougalla w epistemicznym układzie odniesienia naturalizmu", w: Bylica, Kilian, Piotrowski i Sagan (red.), Filozofia - nauka - religia..., s. 165-172, www.nauka-a-religia.uz.zgora.pl/images/Przedruki/Roskal_Eksperyment.Mac Dougalla.pdf (02.07.2018).

RYLAND Mark, „«Teoria inteligentnego projektu» podważa teorię ewolucji. Już sama złożoność stworzenia świadczy o działaniu siły wyższej. Darwinizm? Nie ma szans. Wywiad z Michaelem J. Behe'em dla Our Sunday Visitor", przeł. Dariusz Sagan, Na Początku... 2004, nr 11-12A (187-188), s. 414-420, www.nauka-a-religia.uz.zgora.pl/images/Przedru ki/Ryland_Teoria.ID.podwaza.teorie.ewolucji.pdf(31.01.2018).

SADY Wojciech, „Czego Kazimierz Jodkowski nie dostrzega, jeśli o odkrycia naukowe chodzi?”, w: Bylica, Kilian, Piotrowski i Sagan (red.), Filozofia - nauka - religia..., s. 5964.

SADY Wojciech, „Dlaczego kreacjonizm «naukowy» nie jest naukowy i dlaczego nie prowadzi do teizmu?", Przeglą Filozoficzny - Nowa Seria 2001, R. X, nr 1 (37), s. 213-228, www.nauka-a-religia.uz.zgora.pl/images/Przedruki/Sady_Dlaczego.kreacjonizm.naukowy.n ie.jest.naukowy.pdf (02.02.2018).

SAGAN Dariusz, „Ewaluacja ewolucjonistycznych rozwiązań problemu nieredukowalnej złożoności”, Otwarte Referarium Filozoficzne 2009, t. 2, Genesis. Filozoficzne konsekwencje wyników badań przyrodniczych o początku świata, życia, człowieka, s. 89-116, http:// tiny.pl/q3mjg (23.01.2018).

SAGAN Dariusz, „Filtr eksplanacyjny: wykrywanie inteligentnego projektu na gruncie nauk przyrodniczych", Roczniki Filozoficzne 2009, t. LVII, nr 1, s. 157-193, www.nauka-a-reli gia.uz.zgora.pl/images/Przedruki/Sagan_Filtr.eksplanacyjny.pdf (21.01.2018).

SAGAN Dariusz, „Kazimierz Jodkowski o teorii inteligentnego projektu”, w: BYLICA, KILIAN, Piotrowski i SAGAN (red.), Filozofia - nauka - religia..., s. 213-227, http://www.naukaa-religia.uz.zgora.pl/images/Przedruki/Sagan_Kazimierz.Jodkowski.o.teorii.ID.pdf (18.01. 2018).

SAGAN Dariusz, Metodologiczno-filozoficzne aspekty teorii inteligentnego projektu, $B i$ blioteka Filozoficznych Aspektów Genezy, t. 6, Instytut Filozofii Uniwersytetu Zielonogórskiego, Zielona Góra 2015, www.nauka-a-religia.uz.zgora.pl/images/Przedruki/Sagan_Me todologiczno-filozoficzne.aspekty.ID.pdf (04.02.2018).

SAGAn Dariusz, „Molekularny «zegar Paleya» a darwinowska ewolucja”, Ruch Filozoficzny 2005, t. LXII, nr 2, s. 289-304, www.nauka-a-religia.uz.zgora.pl/images/Przedruki/Sagan Molekularny.zegar.Paleya.pdf (12.02.2018). 
SAGAN Dariusz, „Naturalizm metodologiczny a zagadnienie prawdy w nauce”, w: $Z_{\mathrm{A}-}$ CHARIASZ (red.), Poznanie a prawda..., s. 167-173, www.nauka-a-religia.uz.zgora.pl/image s/Przedruki/Sagan_Naturalizm.metodologiczny.a.prawda.pdf (21.01.2018).

SAGAN Dariusz, „Naturalizm metodologiczny — konieczny warunek naukowości?”, Roczniki Filozoficzne 2013, t. LXI, nr 1, s. 73-91, http://tiny.pl/q33sb (18.01.2018).

Sagan Dariusz, „Retoryczna historia Ruchu Inteligentnego Projektu”, Diametros 2005, nr 4, s. 76-85, www.nauka-a-religia.uz.zgora.pl/images/Przedruki/Sagan_Retoryczna.historia. Ruchu.ID.pdf (07.02.2018).

SAGAN Dariusz, „Spór o możliwość wykrywania projektu w naukach przyrodniczych”, Scientia et Fides 2015, vol. 3, nr 1, s. 87-113, www.nauka-a-religia.uz.zgora.pl/images/ Przedruki/Sagan_Spor.o.mozliwosc.wykrywania.projektu.pdf (12.02.2018).

SAGAN Dariusz, „Teoria inteligentnego projektu - argumenty za i przeciw”, w: JANECZEK, Starościc, DąbeK i Herda (red.), Filozofia przyrody..., s. 335-383, www.nauka-a-religia. uz.zgora.pl/images/Przedruki/Sagan_Teoria.ID.argumenty.za.i.przeciw.pdf (02.01.2018).

SAGan Dariusz, „Zarzut nietestowalności teorii inteligentnego projektu”, Studia Philosophica Wratislaviensia 2013, vol. VIII, fasc. 3, s. 43-59, www.nauka-a-religia.uz.zgora.pl/ima ges/Przedruki/Sagan_Zarzut.nietestowalnosci.teorii.ID.pdf(13.02.2018).

SŁowiK Grzegorz P. i Kilian Krzysztof J., „Hoyle i matematyczne dylematy ewolucjonizmu", w: Bylica, Kilian, Piotrowski i Sagan (red.), Filozofia - nauka - religia..., s. 395-408, http://www.nauka-a-religia.uz.zgora.pl/images/Przedruki/Slowik.Kilian_Hoyle. i.matematyczne.dylematy.ewolucjonizmu.pdf (19.02.2018).

THoRNHILL Richard, „Historyczny związek między darwinizmem a argumentem z biologicznego projektu", przeł. Anna Droś, Natalia Górska, Mateusz Krzyżanowski, Renata Merda, Zofia Sadowska i Dariusz Sagan, Filozoficzne Aspekty Genezy 2012, t. 9, s. 79-105, http:// www.nauka-a-religia.uz.zgora.pl/images/FAG/2012.t.9/art.05.pdf(19.01.2018).

WaLSH William Henry and WILSHIRE Bruce Withington, „Metaphysics”, w: Encyclopedia Britannica, https://www.britannica.com/topic/metaphysics/Types-of-metaphysical-theory\#t oc15845 (15.01.2018).

WeinBerg Steven, Sen o teorii ostatecznej, przeł. Piotr Amsterdamski, Alkazar, Warszawa 1994.

WeINER January, „Hipotezy o powstaniu i wczesnej ewolucji życia. Historia dociekań (od Darwina do Millera)", Kosmos 2009, t. 58, nr 3-4, s. 501-528, http://kosmos.icm.edu.pl/ PDF/2009/501.pdf (31.01.2018). 
Willma Adam, „Przyroda, Bóg, nauka. Rozmowa z profesorem Kazimierzem Jodkowskim”, Gazeta Pomorska 2 listopada 2006, s. 7, www.nauka-a-religia.uz.zgora.pl/images/ Przedruki/Jodkowski_Przyroda.Bog.nauka.pdf (18.01.2018).

WoJnar Anna, „Czy nauka zastąpi religię?”, Alma Mater. Miesięcznik Uniwersytetu Jagiellońskiego 2008, nr 108, s. 91-94, http://www2.almamater.uj.edu.pl/108/22.pdf (20.01. 2018).

WOODWARD Thomas, „Istota sporu darwinizmu z teorią inteligentnego projektu: przyrodnicza symfonia makroewolucji”, przeł. Dariusz Sagan, Filozoficzne Aspekty Genezy 2007/2008, t. 4/5, s. 7-20, http://www.nauka-a-religia.uz.zgora.pl/images/FAG/2007-20 08.t.4-5/art.01.pdf (12.03.2018).

Zachariasz Andrzej L. (red.), Poznanie a prawda, Wydawnictwo Uniwersytetu Rzeszowskiego, Rzeszów 2009.

Zon Józef (red.), Pogranicza nauki. Protonauka - paranauka - pseudonauka, Wydawnictwo KUL, Lublin 2009.

\section{Czym są epistemiczne układy odniesienia?}

\section{Streszczenie}

Niniejszy artykuł wyjaśnia, dlaczego omawiane do tej pory epistemiczne układy odniesienia nigdy nie pełniły roli kryterium demarkacji. Wyjaśnia się tam również, dlaczego epistemiczne układy odniesienia - mimo tego, że są jedynie warunkami koniecznymi naukowości - pełnią w nauce tak istotną rolę. Historia filozofii nauki pokazuje, że sformułowano wiele koniecznych warunków naukowości. Pojawia się zatem pytanie o to, czy epistemiczne układy odniesienia pod jakimiś istotnymi względami różnią się od innych warunków koniecznych. Aby odpowiedzieć na to pytanie, wprowadzono dwie dystynkcje: mocne i słabe oraz materialne i formalne warunki sine qua non.

W artykule zastanawiano się również nad sensownością oddzielania epistemicznych układów odniesienia od programów badawczych i paradygmatów. Na pierwszy rzut oka epistemiczne układy odniesienia mogą być składnikami Popperowskich metafizycznych programów badawczych i twardych rdzeni Lakatosowskich programów badawczych, pełniąc w tych ostatnich rolę mocnych zasad heurystycznych, kierujących badaniami naukowymi. Można też próbować umieszczać je w Kuhnowskich macierzach dyscyplinarnych, gdzie mogą funkcjonować jako składniki wartości lub modeli ontologicznych. Jednak najlepszymi kandydatami na nośniki epistemicznych układów odniesienia są Feyerabendowskie interpretacje naturalne i Lakatosowskie podstawowe sądy wartościujące.

Slowa kluczowe: epistemiczne układy odniesienia, nośniki epistemicznych układów odniesienia, mocne i słabe warunki sine qua non naukowości, materialne i formalne warunki sine qua non naukowości. 


\section{What Are the Epistemic Frameworks?}

\section{Summary}

This paper sets out to explain why it is that epistemic frameworks as discussed so far have never functioned in such a way as to furnish a criterion of demarcation. It also seeks to shed light on why such frameworks, though only sine qua non conditions for what may be considered scientific, nevertheless play a leading role in science. As the history of the philosophy of science shows, there are many sine qua non conditions for counting as scientific. Moreover, it should be asked whether epistemic frameworks differ significantly from other sine qua non conditions. To answer that question, two distinctions are to be introduced with respect to such conditions: between strong and weak ones, and between material and formal ones.

The paper also examines the reasonableness of separating epistemic frameworks from research programs and paradigms. Initially, epistemic frameworks look like they would lend themselves to serving as components of Popperian metaphysical research programs, as well as of the hard cores of Lakatosian scientific research programs. (In the latter instance, they could play the role of strong heuristic rules guiding scientific research.) One may also try to insert them into Kuhnian disciplinary matrices, where they will function as components of values or ontological models. Even so, the best candidates as bearers of such frameworks will be Feyerabendian natural interpretations, together with Lakatosian normative basic judgments.

Keywords: epistemic frameworks, bearers of epistemic frameworks, strong and weak sine qua non conditions for what counts as scientific, material and formal sine qua non conditions for what counts as scientific. 